\title{
QUEM É O ADULTO MADURO PRESENTE NA EDUCAÇÃO PROFISSIONAL E TECNOLÓGICA?
}

\author{
WHO IS THE MATURE ADULT IN PROFESSIONAL AND \\ TECHNOLOGICAL EDUCATION?
}

\author{
Juliane Vanessa Rippel Silveira ${ }^{1}$ \\ Leila Maria Araújo Santos ${ }^{2}$ \\ Cláudia Smaniotto Barin ${ }^{3}$
}

\begin{abstract}
RESUMO
O processo de envelhecimento no cenário educacional é uma questão que carece de estudos e discussões, uma vez que é intrínseco ao ser humano. Nesse sentido, este artigo é um recorte da dissertação de mestrado intitulada "Adultos Maduros na Educação Profissional e Tecnológica: um estudo à luz da diversidade geracional", cujo foco é a diversidade de gerações em classes pósmédio da EPT e procurou compreender quem é esse "aluno maduro", quais são as suas expectativas quando buscam a EPT e como se dá a relação intergeracional em sala de aula. Neste recorte, de caráter bibliográfico, será dada especial atenção ao levantamento realizado para definir a expressão "adultos maduros" para os sujeitos em fase de transição do adulto jovem para o de meia idade, que se estende dos 30 aos 59 anos. Para determinação dessa expressão, optou-se pela teorização de Erik H. Erikson (1976), Juán J. M. Mosquera e Claus Stobäus (1983), Juán J. M. Mosquera (1987) e Helena B. F. Balbinotti (2003; 2005; 2007 e 2012), partindo das definições de suas teorias sobre as fases da vida. Em conclusão, acredita-se que o grande ideal da educação deverá estar alicerçado em práticas pedagógicas coerentes com a realidade de cada aluno. Considerando que uma pessoa na fase adulta vivenciou diversas experiências, tanto na vida pessoal quanto na profissional, espera-se que ela apresente facilidades para fazer associações para determinados assuntos, dificuldades de compreensão em outros e interesse despertado em algo que está relacionado ao seu dia a dia, ao seu ambiente de convívio ou em algum ponto que tenha lhe despertado curiosidade.
\end{abstract}

Palavras-chave: Educação Profissional e Tecnológica. Envelhecimento populacional. Adultos Maduros. Diversidade Geracional.

\begin{abstract}
The aging process in the educational scenario is an issue that needs studies and discussions, since it is intrinsic to the human being. In this sense, this article is an excerpt from the master's dissertation entitled "Mature Adults in Professional and Technological Education: a study in the light of generational diversity", whose focus is the diversity of generations in post-secondary classes of EPT and sought to understand who is this "mature student", what are their expectations when they seek EPT and how does the intergenerational relationship take place in the classroom. In this section, of bibliographic character, special attention will be given to the survey carried out to define the
\end{abstract}

\footnotetext{
${ }^{1}$ Mestranda em Educação Profissional e Tecnológica, Universidade Federal de Santa Maria (UFSM). ORCID: 0000-0002-4472-759X. E-mail: julianevanessa@yahoo.com.br.

2 Doutora em Informática na Educação pela Universidade Federal do Rio Grande do Sul (UFRGS). Professora da Universidade Federal de Santa Maria (UFSM). ORCID: 0000-0002-1513-3717 .E-mail: leilamas@ctism.ufsm.br.

3 Doutora em Química (Físico-Química) pela Universidade de São Paulo (USP). ORCID: 0000-0002-6549-5476. E-mail: claudiabarin@ufsm.br.
} 
expression "mature adults" for subjects in the transition phase from young to middle-aged adults, which range from 30 to 59 years old. To determine this expression, we chose to theorize Erik $\mathrm{H}$. Erikson (1976), Juán JM Mosquera and Claus Stobäus (1983), Juán JM Mosquera (1987) and Helena BF Balbinotti (2003; 2005; 2007 and 2012), departing definitions of their theories about the phases of life. In conclusion, it is believed that the great ideal of education must be based on pedagogical practices consistent with the reality of each student. Considering that a person in adulthood has had several experiences, both in personal and professional life, it is expected that he / she will have facilities to make associations for certain subjects, difficulties in understanding others and interest aroused in something that is related to their day to day. day, to your living environment or at any point that has aroused your curiosity.

Keywords: Professional and Technological Education. Aging population. Mature adults. Generational diversity.

\section{INTRODUÇÃO}

Este artigo é um recorte da dissertação de mestrado intitulada "Adultos Maduros na Educação Profissional e Tecnológica: um estudo à luz da diversidade geracional"”, cujo foco é a diversidade de gerações em classes pós-médio da EPT e procurou compreender quem é esse "aluno maduro", quais são as suas expectativas quando buscam a EPT e como se dá a relação intergeracional em sala de aula.

Neste recorte, será dada especial atenção ao levantamento realizado para definir a expressão "adultos maduros" para os sujeitos em fase de transição do adulto jovem para o de meia idade, que se estende dos 30 aos $59 \operatorname{anos}^{2}$, pois representaram exatamente a faixa etária que se buscou pesquisar. Para determinação dessa expressão, optou-se pela teorização de Erik Homburger Erikson (1976), Juán José Muriño Mosquera e Claus Stobäus (1983), Juán José Muriño Mosquera (1987) e Helena Beatriz Finimundi Balbinotti (2003; 2005; 2007 e 2012), partindo das definições de suas teorias sobre as fases da vida.

A partir da síntese da ideia de um mundo em movimento perpétuo, proposta pelo filósofo pré-socrático Heráclito, Kreutz e Welter (2016) acrescentam que o dinamismo do processo produtivo, com o advento de novas tecnologias, influencia as profissões, impulsionando a busca por uma formação profissional que possa atender as constantes inovações, pois, muitas vezes, somente a formação inicial não é suficiente.

A demanda pelo ensino profissionalizante no Brasil, aumentou significativamente com a oferta da ampliação de diversos cursos, voltados ao mundo do trabalho. Além dos desafios e oportunidades provocados pelo fenômeno da globalização, somam-se a ele os investimentos governamentais nas políticas de ensino profissionalizante, com destaque para a criação da Rede Federal de Educação Profissional, Científica e Tecnológica, instituída por meio da Lei

\footnotetext{
1 Dissertação desenvolvida no Programa de Pós-graduação em Educação Profissional e Tecnológica da Universidade Federal de Santa Maria (UFSM). Linha de Pesquisa: Inovação para a Educação Profissional e Tecnológica.

${ }^{2}$ Limitou-se às pessoas com até 59 anos, pois, àquelas com idade igual ou superior a 60 anos são definidas como Idosas, pelo Estatuto do Idoso (Lei $\mathrm{n}^{\circ}$. 10.741, de 01 de outubro de 2003).
} 
n $^{\text {o }} 11.892$ de 29 de dezembro de 2008 e a composição da população brasileira, a qual aponta para uma rápida e crescente taxa de envelhecimento, com um aumento expressivo da parcela de idosos e redução dos demais grupos etários.

Isto posto, uma das mudanças enfrentadas pelas instituições de ensino é a coexistência de grupos heterogêneos em sala de aula, incluindo diferentes gerações, o que ocasiona comportamentos inerentes a cada uma delas e que, ressaltam Machado e Rodrigues (2013), por existirem nas salas de aulas vários sujeitos, com diferentes saberes, eles demandam performance em níveis diferenciados: seus ritmos são díspares e que, por isso, não se pode unificar a sala, os conteúdos e as atividades como se todos soubessem as mesmas coisas e produzissem no mesmo compasso.

A ênfase na diversidade de gerações em classes da EPT se justifica no fato de que, à medida que a educação profissional foi se transformando para atender as demandas do mundo do trabalho, o perfil do aluno e a escola também mudaram, mas as produções e pesquisas científicas voltadas à educação profissional e tecnológica ainda são incipientes.

O estudo sobre a educação profissional no Brasil provoca a reflexão de uma temática relevante e fundamental para a sociedade, devido à estreita relação que se estabelece entre Estado, sistemas de ensino e mundo do trabalho, dado às diferentes funções que a educação profissional assumiu no decorrer da história da educação brasileira.

Em cada época histórica, os processos educativos são influenciados e organizados a partir das transformações culturais, econômicas e políticas da sociedade, isto é, a partir do modo de produção, da forma de organização socioeconômica das forças produtivas e das relações de produção (ALMEIDA e SUHR, 2012).

No núcleo dos regimes produtivos e na sociedade, a qualificação profissional expressa relações de poder, por isso, Manfredi (2016, p.21) afirma que as noções de trabalho foram "se construindo e reconstruindo ao longo da história das sociedades humanas, variando de acordo com os modos de organização da população e de distribuição de riqueza e poder”.

\section{ENVELHECIMENTO POPULACIONAL}

O processo de globalização aumenta a produtividade e exige a elevação do nível instrucional, então, o processo de transição demográfica, segundo Ávila e Machado (2016), apresenta desafios e oportunidades na educação e impactos no mundo do trabalho. Na perspectiva demográfica, o momento é favorável ao investimento em educação, considerandose a redução no ritmo de crescimento populacional e o aumento na expectativa de envelhecimento populacional.

O Brasil é um país que está envelhecendo a passos largos. Sua estrutura etária vem 
passando por uma significativa transformação. Borges, Campos e Silva (2015), observando os dados da transição demográfica brasileira sob a ótica etária, manifestam que o formato da pirâmide populacional brasileira inverteu: a base larga (com muitas crianças e jovens) e com cume estreito (com poucos idosos) vem dando lugar a uma pirâmide característica de uma população envelhecida, reduzindo a participação relativa de crianças e jovens e com aumento proporcional de adultos e idosos. O exposto pode ser visualizado na Figura $1^{3}$, que apresenta as projeções e as estimativas da população do Brasil e das Unidades da Federação, elaboradas pelo Instituto Brasileiro de Geografia e Estatística (IBGE).

Figura 1 - Projeção da população do Brasil e das Unidades da Federação (2010-2060)

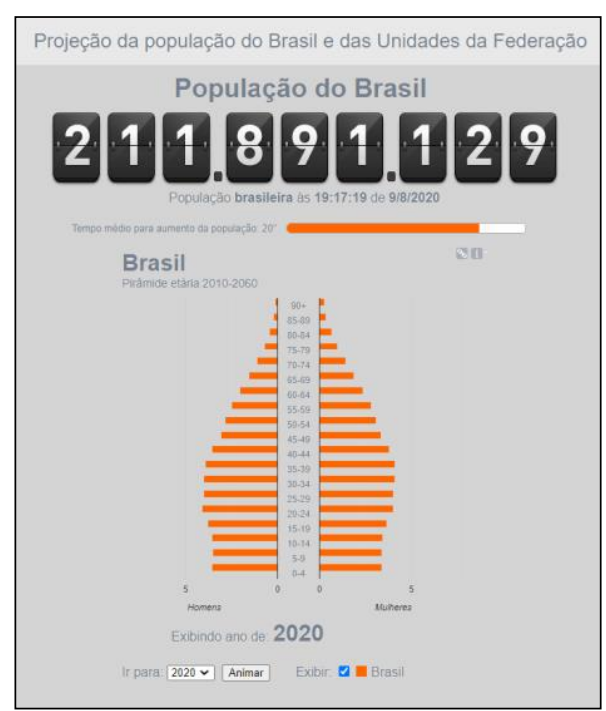

Fonte: Instituto Brasileiro de Geografia e Estatística, 2020.

Importante destacar que o ano de 1985 foi o último ano que a pirâmide etária brasileira teve um "formato egípcio", ou seja, cada grupo etário mais jovem era maior que o grupo imediatamente anterior. Por conta disto, a ciência demográfica habituou-se com o crescimento e com uma estrutura etária jovem, o que fazia com que as políticas públicas se preocupassem essencialmente com a expansão de suas metas quantitativas, tais como maior número de maternidades e pediatrias, mais escolas, mais moradias, mais empregos, mais estradas, mais consumo, etc. (ALVES, 2015).

A conjectura do pico demográfico (máximo da população antes do início do seu decrescimento) brasileiro é pouco mais de vinte anos. O perfil da população vai dar uma "virada" nas próximas décadas, aumentar, estabilizar e, em seguida, a paisagem demográfica vai mudar, vai diminuir e até 2050 o país terá menos crianças de zero a quatro anos do que tinha no último Censo, realizado em 2010 (LEITÃO, 2015). A análise da projeção da

\footnotetext{
${ }^{3}$ Disponível em: <https://www.ibge.gov.br/apps/populacao/projecao/>. Acesso em: 09 ago. 2020.
} 
pirâmide etária brasileira no ano de 2050, apresentada na Figura $2^{4}$, sinaliza o estreitamento da base e o alargamento do topo.

Figura 2 - Projeção da população do Brasil e das Unidades da Federação (2050)

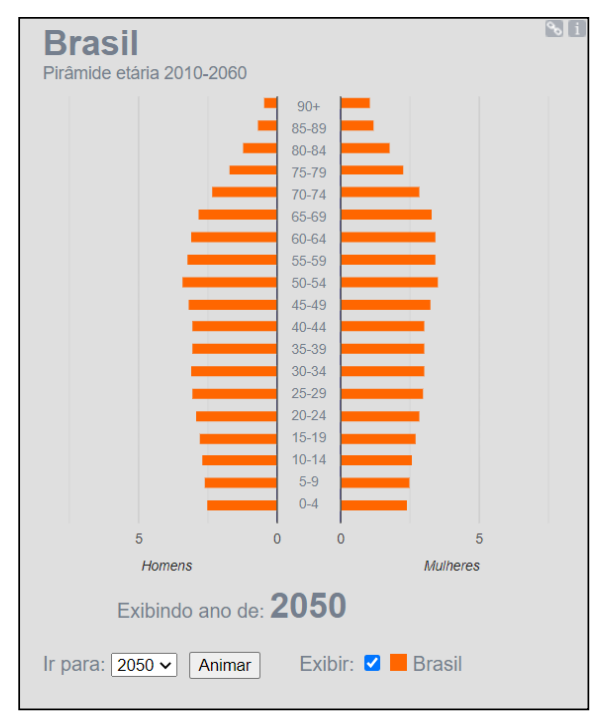

Fonte: Instituto Brasileiro de Geografia e Estatística, 2020.

O envelhecimento populacional traz mudanças tanto para o indivíduo quanto para a sociedade. No que diz respeito ao mundo do trabalho, Buaes (2004) destaca a redução do número de jovens à disposição como força de trabalho e um número bem superior de trabalhadores com mais idade. Um indicador destas mudanças no Brasil é o fato de que, enquanto o número de trabalhadores das faixas etárias até 39 anos está diminuindo, o número de trabalhadores com mais de 40 anos está crescendo, conforme exibe a Figura 3, a qual apresenta o número de pessoas em idade e condições físicas para exercerem algum trabalho, ou seja, a População Economicamente Ativa (PEA).

Figura 3 - População Economicamente Ativa do Brasil (2001-2015) ${ }^{5}$

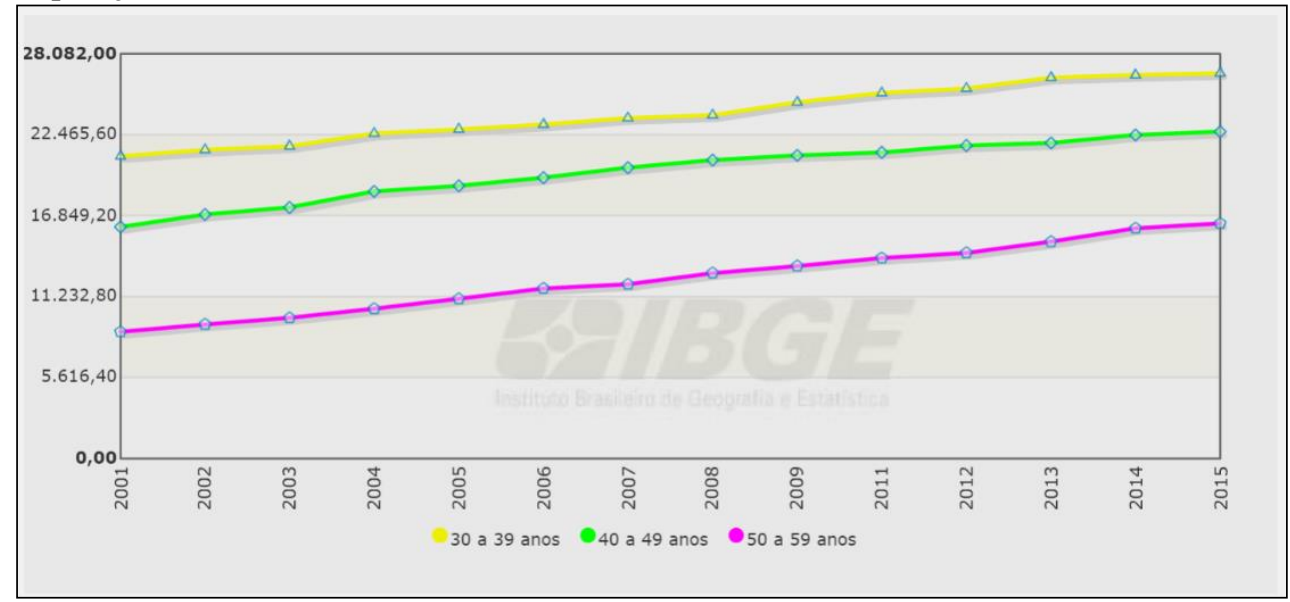

Fonte: Instituto Brasileiro de Geografia e Estatística, 2020.

\footnotetext{
${ }^{4}$ Disponível em: <https://www.ibge.gov.br/apps/populacao/projecao/>. Acesso em: 09 ago. 2020.

${ }^{5}$ Unidade: 1.000 pessoas.
} 
Essa tendência de envelhecimento da força de trabalho vem sendo observada nas últimas décadas. Em 2009, em sua publicação “Anuário dos Trabalhadores”, o Departamento Intersindical de Estatística e Estudos Socioeconômicos (DIEESE) apontou que, entre os anos de 2004 e 2009, houve um aumento gradativo no número de postos de trabalho ocupados por pessoas com mais de 40 anos, passando de 38,70\% para 42\%. Seguindo essa cadência, o Instituto de Pesquisa Econômica Aplicada - IPEA - (2010) ${ }^{6}$, estima que, para o ano de 2040, por volta de $56,30 \%$ da população brasileira em idade ativa será composta por pessoas com mais de 45 anos.

A vertiginosa mudança no perfil etário brasileiro traz inúmeros desafios para o país. A dinâmica das mudanças demográficas nas últimas décadas leva a necessidade de se repensar a perspectiva do envelhecimento da força de trabalho, somando um ingrediente desafiante ao problema da disponibilidade - leia-se, escassez - e retenção de profissionais qualificados para o mundo do trabalho e sustentação do crescimento econômico, pois, muito se fala em Geração $\mathrm{Y}$ e $\mathrm{Z}^{7}$, mas não sobre o envelhecimento dessas gerações; muito se faz pelos jovens, mas pouco se faz pelas gerações mais velhas.

No que diz respeito ao ensino profissional no Brasil, a demanda aumentou significativamente com a oferta da ampliação de cursos técnicos, voltados ao mundo do trabalho. Além dos desafios e oportunidades provocados pelo fenômeno da globalização, somam-se a ele os investimentos governamentais nas políticas de ensino profissionalizante, com destaque para a criação da Rede Federal de Educação Profissional, Científica e Tecnológica, instituída por meio da Lei $\mathrm{n}^{\mathrm{o}}$ 11.892/2008 e a composição da população brasileira, a qual aponta para uma rápida e crescente taxa de envelhecimento, com um aumento expressivo da parcela de idosos e redução dos demais grupos etários.

Eis a necessidade de uma educação inovadora, muito mais do que incluir a tecnologia na rotina dos estudantes, a educação deve promover o diálogo entre as necessidades da sociedade e as possibilidades tecnológicas, é preciso inovar nos recursos pedagógicos, para que se dê um passo à frente na educação dos adultos, na redução dos índices de evasão escolar e na criação de políticas públicas que acolham àqueles que, de alguma foram, foram excluídos pela ineficiência das práticas educacionais e aqueles que, hoje estão na condição de jovens,

\footnotetext{
${ }^{6}$ Instituto de Pesquisa Econômica Aplicada (IPEA). Comunicados do IPEA: PNAD 2009 - Primeiras Análises: Tendências demográficas, $\quad$ n. 64.2010 .20 Disponível $\quad$ em: <https://www.ipea.gov.br/portal/images/stories/PDFs/comunicado/101013_comunicadoipea64.pdf >. Acesso em: 13 set. 2020.

${ }^{7}$ Geração Y ou Millennials é a geração de pessoas nascidas entre os anos de 1980 e 1995 . Por terem nascidos em um mundo totalmente globalizado, também, é chamada de Geração do Milênio ou Geração da Internet. Os nascidos entre os anos de 1996 e 2010 são a Geração Z ou Centennials, nasceram na era da tecnologia e não conseguem imaginar a vida sem ela. Disponível em: $<$ https://dotgroup.com.br/ebook/e-book-as-geracoes-e-suas-formas-de-aprender/>. Acesso em: 13 set. 2020.
} 
mas que serão protagonistas no cenário de envelhecimento de suas gerações.

A educação não é alheia às transformações ocorridas pelo processo de globalização e às exigências por ela demandada. Ao exposto, corrobora Segnini (2000) que a educação e a formação profissional são agentes no processo de competitividade e concorrência, adaptando os sujeitos/trabalhadores às mudanças técnicas e minimizando os efeitos do desemprego.

Isto posto, uma das mudanças enfrentadas pelas instituições de ensino é a coexistência de grupos heterogêneos em sala de aula, incluindo diferentes gerações, o que ocasiona comportamentos inerentes a cada uma delas e que, ressaltam Machado e Rodrigues (2013), por existirem nas salas de aulas vários sujeitos, com diferentes saberes, eles demandam performance em níveis diferenciados: seus ritmos são díspares e que, por isso, não se pode unificar a sala, os conteúdos e as atividades como se todos soubessem as mesmas coisas e produzissem no mesmo compasso.

Um olhar nos dados do Censo Escolar da Educação Básica $2019^{8}$, revela um aumento no número de matrículas na educação profissional de 0,60\% em relação ao ano de 2018. Com um aumento de 11.519 novos alunos, o censo registrou 1.914.749 matrículas nesta modalidade de ensino (Figura 4). Ainda, de acordo com a pesquisa, o crescimento da educação profissional foi sustentado pelas matrículas na modalidade de formação subsequente, com 68 mil matrículas a mais $(7,60 \%)$ no ano e a formação integrada, com acréscimo de 38,6 mil (6,60\%) estudantes.

Figura 4 - Número de matrículas da Educação Profissional por modalidade, Brasil, 2015-2019

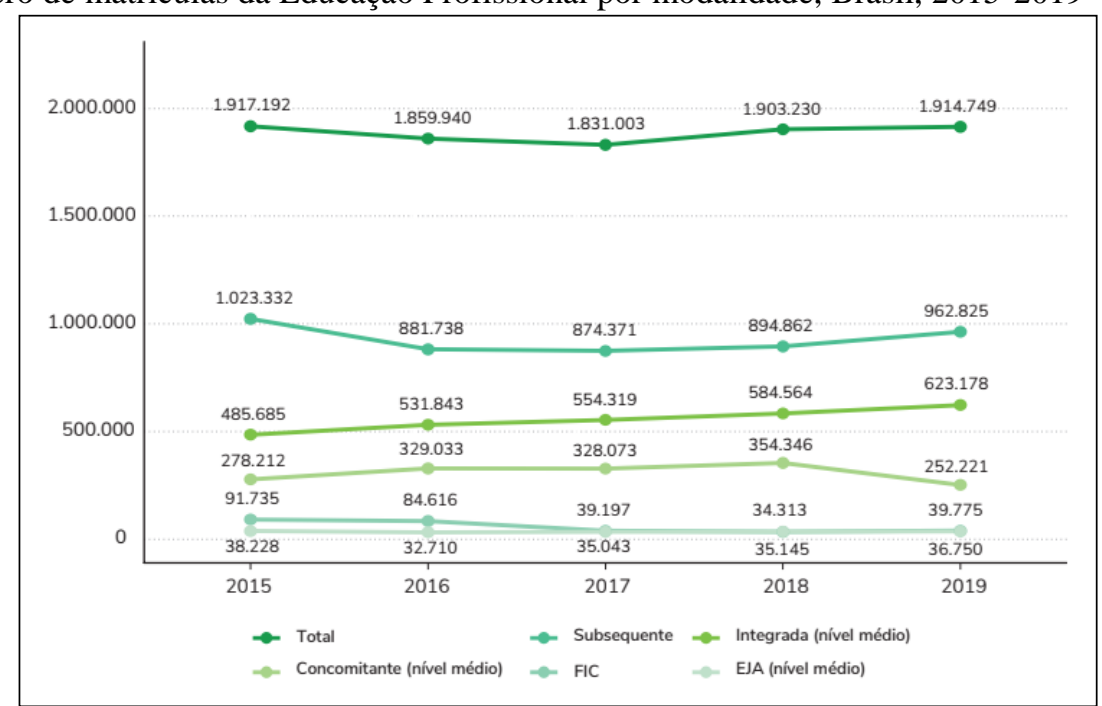

Fonte: Ministério da Educação, Diretoria de Estatísticas Educacionais (DEED), 2020.

Analisando a faixa etária dos alunos matriculados na educação profissional, conforme apresentado na Figura 5, o Censo Escolar 2019 destaca que, a maior parte dos alunos que

\footnotetext{
${ }^{8}$ É um retrato da educação brasileira realizado anualmente pelo Instituto Nacional de Estudos e Pesquisas Anísio Teixeira (Inep), autarquia vinculada ao Ministério da Educação.
} 
frequentam a educação profissional tem até 30 anos, ou seja, 78,80\% do total de matrículas. Desse total, existe uma predominância de matrículas de mulheres na educação profissional em praticamente todas as faixas etárias, exceto dos alunos com mais de 60 anos. A maior diferença foi observada na faixa que vai dos 40 a 49 anos, elas são a maioria, com $62 \%$ de quem frequenta a educação profissional.

Figura 5 - Número de matrículas da EPT por faixa etária e sexo, Brasil, 2019

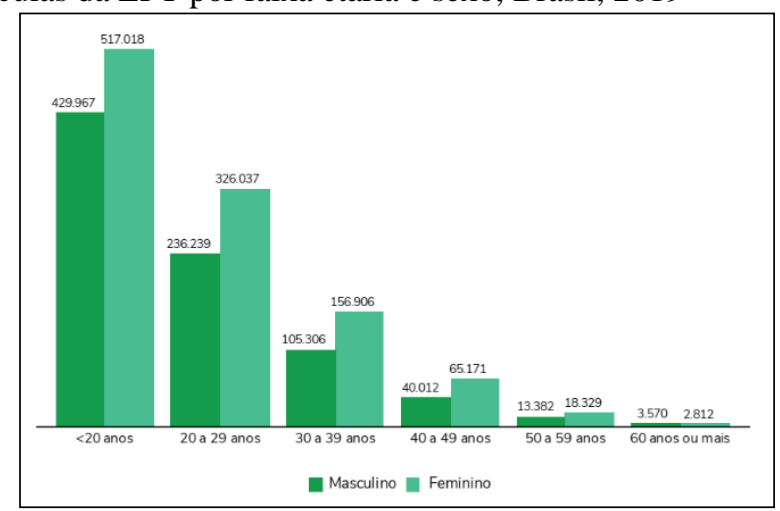

Fonte: Ministério da Educação, Diretoria de Estatísticas Educacionais (DEED), 2020.

A educação, assim como a sociedade, vive um momento de mudança, buscando integração com a diversidade, afirmando cada vez mais sua função social. Nesse contexto e, dentro da configuração demográfica atual, tem-se o surgimento de um contingente de sujeitos que retornam aos estudos na fase adulta. Esse grupo se dedica a resgatar oportunidades que por uma razão ou outra lhes foram negadas anteriormente, que é o caso dos que buscam a educação profissional nessa etapa da vida.

Essa realidade é cada vez mais crescente e evidente. Em 2016, o Instituto Federal do Pernambuco (IFPE) ${ }^{9}$, divulgou que contava com aproximadamente 1.100 estudantes com mais de 50 anos, distribuídos na modalidade de Educação de Jovens e Adultos e outra monta, aposentados e profissionais com formação superior. Segundo o IFPE, a motivação e os objetivos que levam esses estudantes de volta à sala de aula são os mais diversos. Ainda, acredita que, essa situação é reflexo do envelhecimento populacional e, associa a esse fenômeno, as pesquisas acadêmicas que relacionam educação à velhice e os benefícios sugeridos para quem continua estudando, como qualidade de vida, bem-estar físico e mental, segurança financeira, aumento da participação e adaptação social e até redução de custos com saúde.

Com o aumento da expectativa de vida, as pessoas vão trabalhar por mais tempo. Daí a necessidade das pessoas, empresas e governos se prepararem para as transformações do mundo do trabalho, ditadas pela inovação, pela globalização e pelo envelhecimento. No caso

9 Disponível em: <https://www.ifpe.edu.br/imprensa/banco-de-pautas/de-volta-a-sala-de-aula-o-retorno-aosestudos-na-fase-adulta-e-realidade-cada-vez-mais-frequente>. Acesso em: 08 set. 2020. 
brasileiro, no que diz respeito à educação profissional, em que a qualificação é assunto não somente de instituições privadas, mas, principalmente, de instituições públicas, conhecer o indivíduo que se qualifica é fundamental para tornar as políticas públicas mais efetivas, identificar suas fraquezas e direcioná-las para o público-alvo das mesmas com maior eficácia (MUSSE e MACHADO, 2013).

Embora a heterogeneidade seja admitida como uma característica, lidar com ela na prática não é o mesmo, e muitos questionamentos estão presentes no dia a dia de quem ensina. Nesse sentido, para desenvolvimento deste estudo, tomamos como ponto de partida o interesse de alunos com idade igual ou superior a 30 anos, pelos cursos técnicos subsequentes na educação profissional e tecnológica de nível médio, a qual apresenta expressivo número de matrículas, conforme ratifica a Figura 6.

Figura 6 - Número de matrículas da EPT, Cursos Técnicos Subsequentes, por faixa etária e sexo, Brasil, 2019

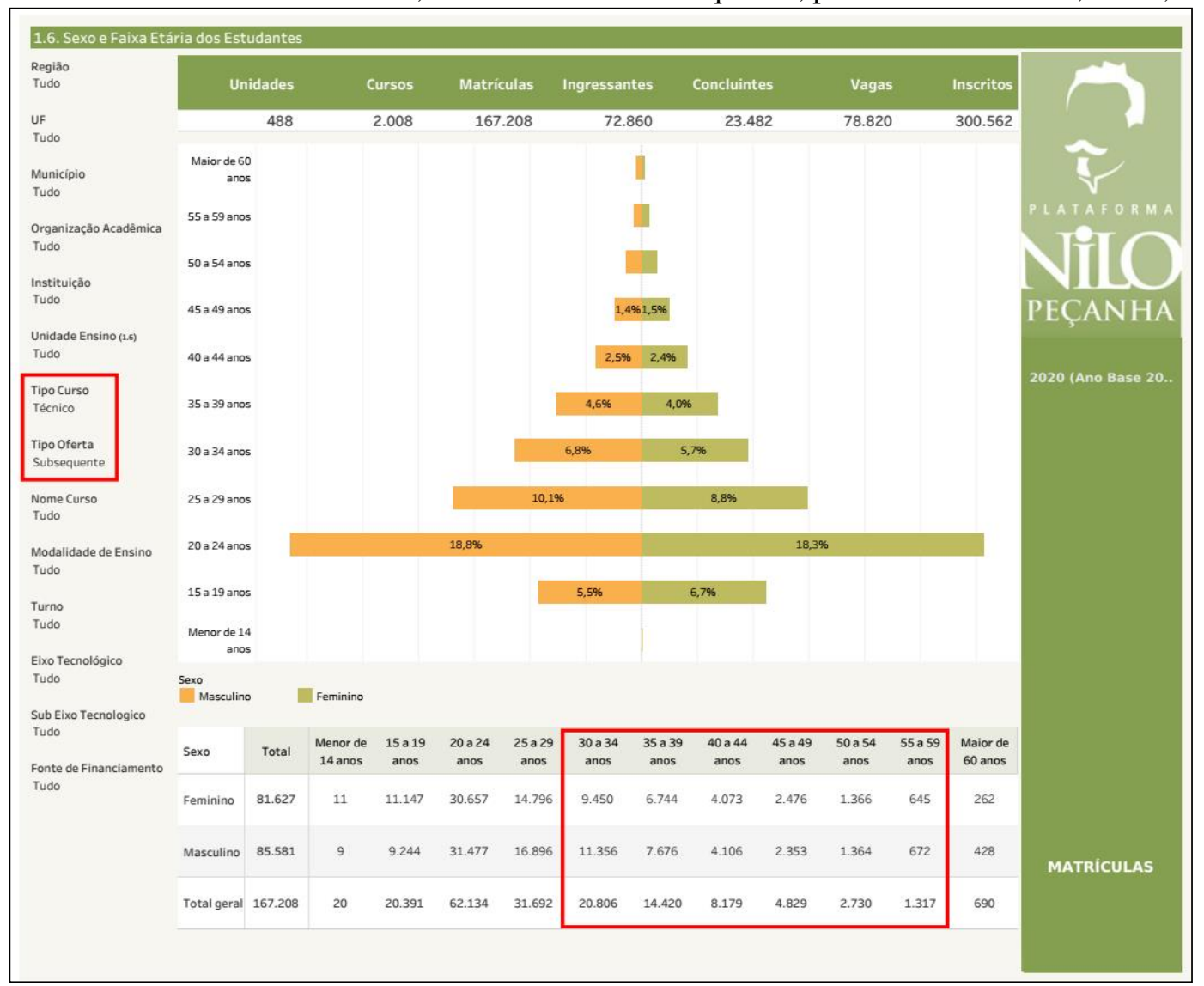

Fonte: Instituto Nacional de Estudos e Pesquisas Anísio Teixeira - Inep, 2020 (grifo nosso).

A carência de estudos e pesquisas relacionados à presença desse público nas turmas dos cursos técnicos subsequentes da educação profissional e tecnológica, indica a necessidade de ampliação do olhar para estes sujeitos, que tende a aumentar nos próximos anos, por conta da redução do número de adolescentes e jovens no ensino profissional e a ampliação do período de vida ativa: 
Se por um lado a longevidade dos indivíduos decorre do sucesso de conquistas no campo social e de saúde, o envelhecimento como um processo, representa novas demandas por serviços, benefícios e atenções que se constituem em desafios para governantes e sociedade do presente e do futuro (BERQUÓ, 1996, p. 32).

Para estudar as percepções e entendimentos e/ou desconhecimentos acerca desses sujeitos, faz-se necessário uma maior compreensão das características que permeiam a vida adulta. Durante seu desenvolvimento, o ser humano passa por diferentes estágios, uma série ininterrupta e eterna de instantes nos prende naquilo que denominamos de ciclos ou fases. Desde nossa infância, adolescência e fase adulta, esse circuito de início e fim em etapas desenham nossa existência.

\section{O ADULTO MADURO}

Considerando a intergeracionalidade presente na modalidade pós-médio da EPT, este estudo adotará o uso da expressão "adultos maduros" para os sujeitos em fase de transição do adulto jovem para o de meia idade, que se estende dos 30 aos 59 anos, pois representarão exatamente a faixa etária que se pretende pesquisar.

Para determinação dessa expressão, optou-se pela teorização de Erik Homburger Erikson (1976), Juán José Muriño Mosquera e Claus Stobäus (1983), Juán José Muriño Mosquera (1987) e Helena Beatriz Finimundi Balbinotti (2003; 2005; 2007 e 2012), partindo das definições de suas teorias sobre as fases da vida, as quais serão apresentadas nas seções seguintes.

\section{A identidade do adulto maduro interpretada a partir da teoria de Erik Erikson}

Um autor que vai nos ajudar a entender as fases da vida adulta é o psicanalista alemão Erik Homburger Erikson (1902 - 1994). Parte integrante do círculo íntimo de Freud em Viena até fugir da ameaça do Nazismo e ir para o Estados Unidos em 1933, Erikson mudou o enfoque da teoria freudiana (sobre desenvolvimento psicossexual) para o problema da identidade e das crises do ego, ancorado em um contexto sociocultural, ou seja, a influência da sociedade sobre o desenvolvimento da personalidade (CHIUZI, PEIXOTO e FUSARI, 2011).

Sua teoria é voltada e focada para o desenvolvimento do ego ao longo do ciclo vital, pois, a construiu a partir da crença que a pessoa evolui durante toda a vida e interage constantemente com o meio ambiente. Para Erikson, o ego é a ferramenta que o indivíduo dispõe para organizar informações externas, testar percepções, selecionar memórias, realizar 
ações adaptativas e integrar capacidades de orientação e planejamento (EIZIRIK et al., 2013)

De postura heterodoxa, Erikson veio conferir ao pensamento neofreudiano ${ }^{10}$ uma vertente mais social e, em meados do século $\mathrm{XX}$, sempre considerando o ser humano como um ser social, que vive em grupo e sofre a pressão e a influência deste, começa a construir uma teoria acerca do desenvolvimento humano em oito estágios psicossociais: os primeiros quatro estágios são decorrentes do nascimento do bebê ao decorrer da infância e, os últimos quatro estágios são referentes à idade adulta e a velhice.

Comparado a seus teóricos contemporâneos, Erikson destacou-se em relação aos demais, ao considerar, na sua teoria, o ciclo vital como um processo contínuo que não se encerra na adolescência, mas perpassa a vida adulta até a velhice e que ele não é resultado apenas de fatores biológicos, mas da articulação desses com fatores sociais e individuais, destacando a importância da cultura para o desenvolvimento saudável dos sujeitos, oferecendo um arcabouço teórico extremamente rico para pensarmos um objeto tão complexo como a educação, a qual é influenciada por questões sociais, culturais, econômicas e políticas (CARPIGIANI, 2010).

A importância da teoria de desenvolvimento psicossocial de Erik Erikson, está em conhecer o comportamento do ser humano ao longo das etapas da vida e as principais influências nestes ciclos. Ainda que, sua teoria tenha sido desenvolvida (e publicada) na década de 1950 e o comportamento do ser humano sofre influências de acordo com a época em que vive, seu estudo pode ser proveitoso ao educador, no meio acadêmico, no ambiente empresarial e, inclusive, em uma comunidade, defende Beck (2018).

Sua teoria identifica oito estágios evolutivos - ou do desenvolvimento do ego -, (Figura 9), sendo que, cada estágio é atravessado por uma crise ${ }^{11}$ psicossocial, sendo uma vertente positiva e outra negativa e, cada fase influencia a seguinte. Em cada uma das fases, o sujeito tem de resolver uma crise resultante do conflito com o qual o meio social o confronta, a partir de então, cada crise vai subsidiando a construção da personalidade num perpétuo movimento que relaciona e dá sentido às memórias e experiências vividas num determinado momento (idade) da vida com as experiências vivenciadas nos estágios anteriores (CARPIGIANI, 2010; CHIUZI, PEIXOTO e FUSARI, 2011; EIZIRIK et al., 2013).

Como pode ser observado na Figura 7, em cada estágio do desenvolvimento, a pessoa poderá estar diante de um determinado problema inevitável, que traduz o seu dilema nesta fase e terá que confrontá-lo. À medida que soluciona uma crise está apta a passar para a fase

\footnotetext{
${ }^{10} \mathrm{O}$ termo neofreudiano tem sido usado para designar os teóricos das correntes ou variantes da psicanálise, os quais concordaram com os conceitos básicos das teorias de Freud, mas modificaram de alguma forma a incluir suas próprias ideias.

${ }^{11}$ Erikson ampliou o conceito de "crise" e mais tarde utilizou o termo conflito ou tendências competitivas.
} 
seguinte. Por isso, cada estágio se distingue por sua tarefa particular de desenvolvimento, por sua relação com os estágios anteriores e ulteriores, pelo papel que desempenha na configuração total do desenvolvimento (FIEDLER, 2016).

Figura 7 - Os estágios psicossociais da teoria de Erik Erikson $x$ crise a ser vivenciada

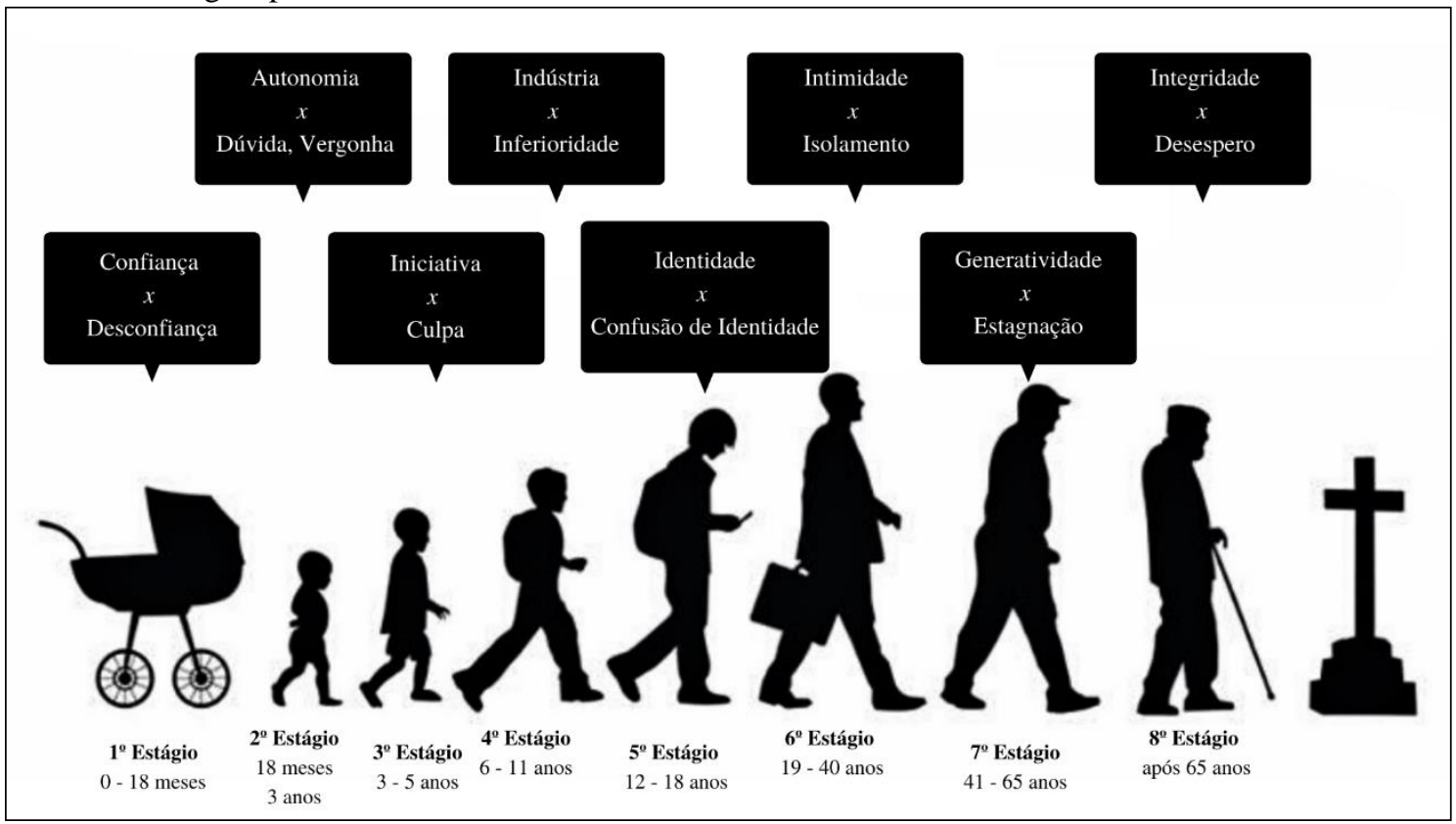

Fonte: Elaborado pelas autoras.

De acordo com Erikson, o termo crise não designa uma tragédia, mas aponta para a possibilidade de mudanças, de crescimento, de desenvolvimento, e, por acontecer com grande parte das pessoas, nesses casos, a crise é normativa:

[...] pela importante descoberta de Freud de que o conflito neurótico não é muito diferente, no conteúdo, dos conflitos "normativos" por que todas as crianças têm de passar em sua infância e cujos resíduos todos os adultos conservam nos recessos de suas personalidades. Com efeito, o homem, a fim de manter-se psicologicamente vivo, re-resolve constantemente esses conflitos, tal como seu corpo combate incessantemente as investidas da deterioração física (ERIKSON, 1976, p. 90).

Noack (2007) destaca que, a crise de identidade é social, porque essa identidade deve ser encontrada dentro da comunidade à qual o indivíduo pertence e depende durante toda vida do suporte de modelos sociais. Aqui, revela-se o lado psico-histórico da crise de identidade, pois os modelos sociais correspondem a uma respectiva época histórica.

Embora o interesse direto do tema desta pesquisa sejam o $6^{\circ}$ e $7^{\circ}$ estágios de desenvolvimento, optou-se aqui, em explicar a todos de forma sintética, evitando assim uma fragmentação reducionista demasiada do entendimento da Teoria de Erik Erikson. 
A partir do diagrama epigenético ${ }^{12}$ formulado por Erikson, retratado na Figura 8, o qual apresenta a progressão, no tempo e no espaço, do desenvolvimento pessoal, cada um dos oito estágios sugere uma crise vertical que culmina em uma solução psicossocial e, ao mesmo tempo, uma crise horizontal que se relaciona, da ótica pessoal e social, com o problema das motivações de cada estágio maturacional.

Observando o diagrama, da infância à velhice, os estágios delineiam uma condição afetiva em relação à solução de cada tarefa: 1) sentido de confiança; 2) sentido de autonomia; 3) sentido de iniciativa; 4) sentido de produtividade pessoal; 5) sentido de identidade; 6) sentido de intimidade; 7) sentido de generatividade e 8) sentido de integridade (ERIKSON, 1976).

Figura 8 - Diagrama epigenético de Erik Erikson

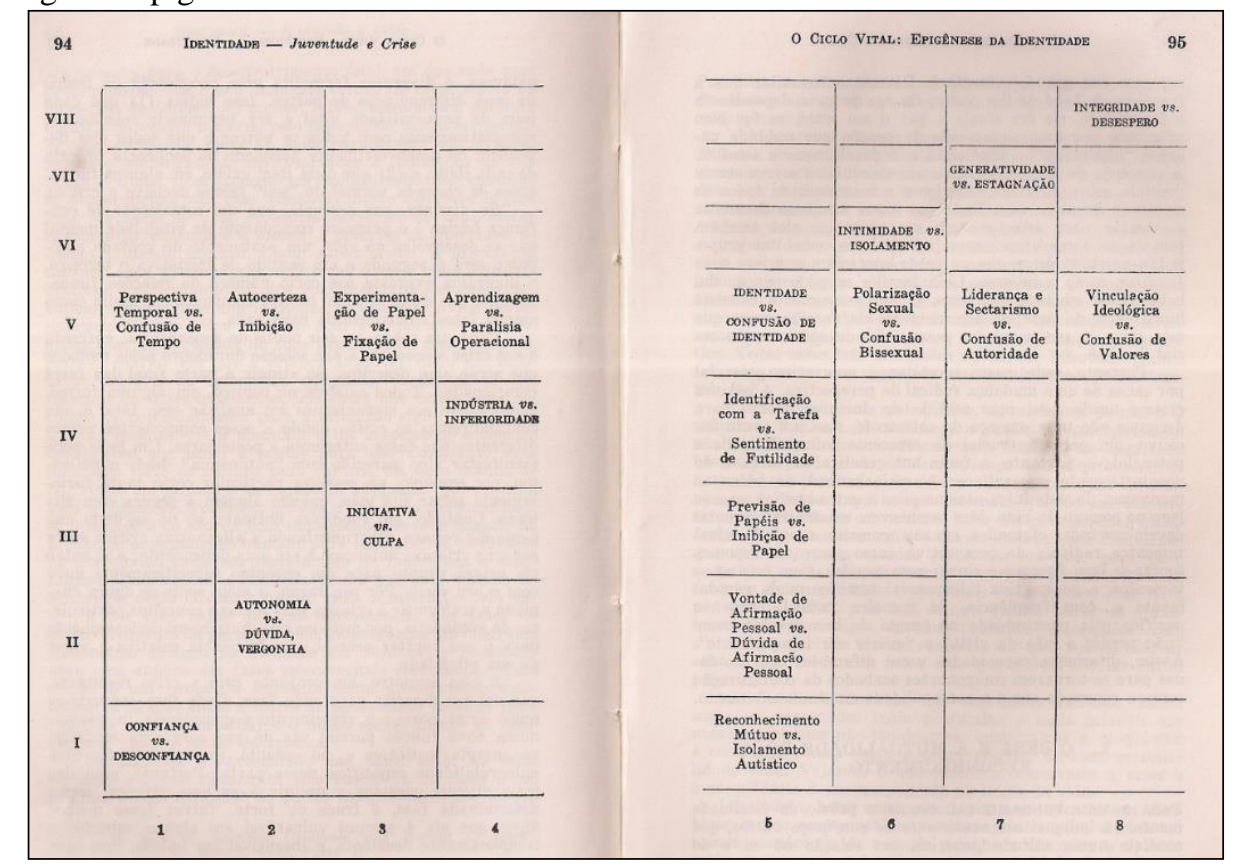

Fonte: ERIKSON, 1976, p. 94-95.

O primeiro estágio, intitulado confiança básica $x$ desconfiança básica, é o período que vai do nascimento até aproximadamente 18 meses de vida do bebê, no qual ele desenvolve o senso de perceber se o mundo é um lugar bom e seguro, a partir do relacionamento com as pessoas e objetos de seu mundo. Nesta fase, a tarefa do indivíduo consiste na construção de um equilíbrio dinâmico entre a confiança e desconfiança. Este primeiro ano de vida, é marcado pela relação e cuidados que se estabelece com a mãe ${ }^{13}$ (CARPIGIANI, 2010; CHIUZI, PEIXOTO e FUSARI, 2011). Papalia e Feldman (2013) destacam que, se a

\footnotetext{
${ }^{12}$ A Teoria Epigenética é um princípio desenvolvido por Erik Erikson, que afirma que cada estágio psicossocial serve de base para o subsequente (EIZIRIK et al., 2013).

${ }^{13}$ A expressão mãe, representa a pessoa que cuida da criança ou do adolescente, a figura que presta os cuidados e com que se estabeleceu uma relação afetiva que, na maioria dos casos da nossa cultura, é a mãe biológica.
} 
confiança predominar, a criança desenvolve a virtude da esperança, do contrário, o mundo será visto por ela como um lugar hostil e imprevisível e terá dificuldade para estabelecer relacionamentos.

Entre os primeiros 18 meses de vida e os três anos de idade ocorre o segundo estágio psicossocial, autonomia $x$ dúvida, vergonha. Nesse estágio, o desenvolvimento de competências motoras e da linguagem conferem à criança o sentido de autonomia. Aqui, a criança começa a substituir o julgamento dos seus cuidadores pelo seu próprio julgamento, ou seja, se dá a passagem do controle externo para o autocontrole. No entanto, elas precisam ter seus limites estabelecidos pelos adultos, assim, a vergonha e a dúvida surgem face à desaprovação (PAPALIA e FELDMAN, 2013). A crise fundamental desta fase está na ambivalência de afirma-se como pessoa e a autonegar-se o direito e a capacidade de realizar esta afirmação (FIEDLER, 2016).

O terceiro estágio é chamado de inciativa x culpa, se dá entre os três aos cinco anos de idade, quando a criança ingressa na escola e é marcado por uma crescente destreza e senso de responsabilidade. Agora, uma vez que a criança conseguiu a confiança e a autonomia, nas fases anteriores, cabe associá-las à iniciativa, pela expansão intelectual. Essa combinação dá à criança um sentimento de determinação, alavanca para a iniciativa. A essência deste terceiro estágio são os sentimentos conflitantes do crescente desejo de planejar e executar atividades e as crescentes dores de consciência que a criança pode ter a respeito desses planos (CHIUZI, PEIXOTO e FUSARI, 2011; LEITE e SILVA, 2019; PAPALIA e FELDMAN, 2013).

A quarta fase Eriksoniana é denominada indústria $x$ inferioridade. De acordo com Leite e Silva (2019), a criança está entre os seis anos de idade e o início da puberdade, que se dá por volta dos 11 anos. Nesta etapa do desenvolvimento, o mundo da criança estende-se agora à escola. Ela aprende o que é valorizado no mundo adulto, e tenta se adaptar a ele, projetando-se no futuro. Dirige, portanto, suas energias no sentido de capacidade e produtividade pessoal (FIEDLER, 2016). Segundo Carpigiani (2010, p. 15), ao se perceber capaz de fazer a coisas e fazê-las bem, ela "desenvolve um sentimento de domínio e de industrialidade ao ser bem sucedida, como também desenvolve o sentimento de inferioridade, de apego à mãe, ao considerar-se mal sucedida".

O conceito de indústria é visto por Erikson (1976) como significando estar ocupado com algo, aprender a completar algo, ter um trabalho a realizar:

[...] e embora todas as crianças precisem de suas horas e dias de fantasia lúdica, mais cedo ou mais tarde todas elas acabarão descontentes e mortificadas sem um sentimento de serem capazes de fazer coisas, fazê-las bem e até perfeitamente; foi a isto que demos o nome de sentimento de indústria (p. 124). 
A falta de sucesso na resolução das tarefas torna a criança mais dependente e desenvolve sentimentos de incapacidade e inferioridade (CHIUZI, PEIXOTO e FUSARI, 2011).

Carpigiani (2010) aponta que, esses quatro primeiros estágios formam a primeira infância e, a vivência de seus conflitos fornecem à entrada na adolescência.

Intitulado identidade versus confusão de identidade, o quinto estágio ocorre no período entre os 12 aos 18 anos. A crise normativa é a construção da identidade e surge face às mudanças físicas (maturação genital), cognitivas e sociais com que o indivíduo se confronta na adolescência (CARPIGIANI, 2010). Este é o momento de integrar todos os elementos que já adquiriu nos estágios anteriores para encontrar e fortalecer sua identidade:

[...] num período da vida em que o corpo muda radicalmente suas proporções, em que a puberdade genital inunda o corpo e a imaginação com toda a espécie de impulsos, em que a intimidade com o outro sexo se aproxima e, ocasionalmente, é imposta à pessoa jovem e em que, enfim, o futuro imediato a coloca diante de um número excessivo de possibilidades e opções conflitantes (ERIKSON, 1976, p. 133).

Aqui, sublinha Fiedler (2016), se adquire a identidade psicossocial, é preciso o adolescente entender seu papel no mundo e reconhecer sua singularidade, assim, passa a constituir uma busca constante, ansiosa e angustiante, desta fase:

[...] necessidade da pessoa jovem de desenvolver um sentimento de identidade, visto que, entre todas as relações possíveis e imagináveis, ele deve fazer uma série de seleções cada vez mais limitadas de cometimentos pessoais, ocupacionais, sexuais e ideológicos (ERIKSON, 1976, p. 246-247).

Para Erikson, segundo Papalia e Feldman (2013), a identidade forma-se quando os jovens resolvem três questões importantes: a escolha de uma ocupação, a adoção de valores sob os quais viver e o desenvolvimento de uma identidade sexual satisfatória.

Cabe ressaltar que, as próximas duas fases do desenvolvimento abarcam os sujeitos objeto de interesse direto do tema desta pesquisa.

A partir da identidade construída na adolescência, o sexto estágio é batizado de intimidade versus isolamento. Este estágio corresponde ao início da vida adulta, manifesta-se por volta dos 19 aos 40 anos de idade. Aqui, a tarefa do jovem adulto, como é denominado o sujeito desta idade, é a de desenvolver relações de amizade, de afeto com os outros, ou seja, relacionamentos íntimos nutridores. Caso não consiga estabelecer esses laços sociais, pode isolar-se e acabar distanciando-se dos outros (CHIUZI, PEIXOTO e FUSARI, 2011).

Nessa fase do desenvolvimento, a instituição social que está associada a esta idade é a estrutura social de sistemas éticos, aponta Carpigiani (2010). A autora esclarece que, após ter 
encontrado sua identidade, o jovem se dispõe a ligar sua identidade com a de outros, não apenas no contexto das relações amorosas, mas também no contexto das relações de amizade, sentindo-se confortável consigo mesmo:

Mas, à medida que as áreas de responsabilidade adulta são gradualmente delineadas, quando o encontro competitivo, o vínculo erótico e a inimizade irredutível são diferenciados uns dos outros, elas acabam ficando sujeitas àquele sentimento ético, que é a marca do adulto e que sucede à convicção ideológica da adolescência e ao moralismo da infância (ERIKSON, 1976, p. 137).

Erikson (1976) entende que intimidade é a capacidade de fundir a sua identidade com a de outro indivíduo, sem temer estar perdendo sua própria identidade, embora esse seja o receio do adulto jovem:

O indivíduo é ameaçado de um súbito colapso de toda a sua capacidade de mutualidade, seguindo-se-lhe um desespero desejo de começar tudo de novo, com uma regressão (quase deliberada) a uma fase de perplexidade e raiva básicas, como só uma criança muito pequena pode experimentar (ERIKSON, 1976, p. 168).

A intimidade que se busca neste estágio do desenvolvimento compreende uma fusão de identidades nas relações de trabalho, sexuais ou de amizades que podem se tornar complementares, reforça Stella (2009). Ainda, segundo a autora, ao final desta fase, compete ao indivíduo afirmar sua identidade como adulto independente de suas relações parentais ou de seu grupo de pariformes, comprometendo-se com associações concretas que exijam compromissos significativos, nos quais possa ter intimidade.

A crise psicossocial do adulto jovem consiste em alcançar o senso de intimidade com outros adultos da mesma idade, sobretudo com outro indivíduo do sexo oposto. No momento que essa intimidade é alcançada e o outro indivíduo mostra que é capaz de dividir significativamente e o que ele é com o outro, ele pode se tornar um indivíduo socialmente ajustado, caso não consiga essa intimidade, passará a experimentar o senso de isolamento e provavelmente será um indivíduo socialmente inadequado e improdutivo, avalia Erikson (1976).

De acordo com Bordignon (2005), a intimidade é a força responsável que leva o jovem adulto a confiar em alguém, com quem partilhará, em confiança mútua e regular, os ciclos de vida reprodutiva, laboral e de lazer, com o intuito de assegurar melhores condições de vida e de trabalho para as gerações futuras. Ainda, acrescenta o autor, o isolamento contrapõe essa situação, por isso, um justo equilíbrio entre intimidade e isolamento reforça a capacidade para a realização do amor e da prática profissional.

A partir da teoria de Erik Erikson, Chiuzi, Peixoto e Fusari (2011) traçaram uma análise sobre o fenômeno social do conflito de gerações nas organizações e concluíram que 
esse sentimento é percebido como presente nos membros da Geração $X^{14}$, que hoje estão entre os 39 e 55 anos de idade, os quais anseiam por moderação entre trabalho e vida familiar. Ambicionam uma carreira de sucesso, mas confiam que o empenho ao trabalho deve atender um perímetro, demarcado pelo fato de poderem desfrutar e vivenciar o relacionamento íntimo com sua família e filhos.

Acontecimentos e realizações intensos caracterizam essa etapa da vida. Os indivíduos deste ciclo de desenvolvimento, de acordo com Stella (2009) participam de ritualizações associativas, nas quais os parceiros de sexo, amizade, cooperação e competição acabam por manter estilos, formas de comportamento e linguagens próprios de um grupo do qual fazem parte. Mesmo com estilos de vida compartilhados, os jovens adultos utilizam da solidariedade como ligação entre os outros membros do grupo, porém conservam sua identidade individual.

Segundo a teoria de Erikson, evidencia Beck (2018), quando atingimos esta fase, nos centramos no desenvolvimento social e emocional. Aqui, surgem os relacionamentos, as responsabilidades, a inserção em ambientes que antes não tínhamos contato e que, agora, demandam por decisões importantes, afetando o desenvolvimento pessoal. As motivações e ambições do indivíduo são afetadas diretamente pela relação com a família, amigos, colegas de trabalho e com o (a) parceiro (a) íntimo (a): neste estágio o interesse consiste em conseguir um trabalho, buscar uma promoção, ser visto como uma pessoa de sucesso.

Nesse período da vida humana, ao combinarem as mudanças críticas do desenvolvimento psicossocial com o desenvolvimento físico e cognitivo, Papalia e Feldman (2013, p. 41) concluíram que, os jovens adultos estão no auge de sua força, energia e resistência, no entanto, continuam a se desenvolver em todas as suas dimensões e fazem escolhas importantes para sua saúde, felicidade e sucesso:

A condição física atinge o auge, depois declina ligeiramente. Opções de estilo de vida influenciam a saúde [desenvolvimento físico]. O pensamento e os julgamentos morais tornam-se mais complexos. São feitas escolhas educacionais e vocacionais, às vezes após um período exploratório [desenvolvimento cognitivo]. Traços e estilos de personalidade tornam-se relativamente estáveis, mas as mudanças na personalidade podem ser influenciadas pelas fases e acontecimentos da vida. São tomadas decisões sobre relacionamentos íntimos e estilos de vida pessoais, mas podem não ser duradouros. A maioria das pessoas casa-se e tem filhos [desenvolvimento psicossocial] (grifos nosso).

No que diz respeito à educação, quando o indivíduo se encontra nesta fase, o papel do

\footnotetext{
${ }^{14}$ Refere-se aos indivíduos nascidos entre meados da década de 1960 e o início da década de 1980. Ainda que valorizem a estabilidade, buscam a ascensão profissional. Por terem que superar os conflitos econômicos ocorridos entre os anos de 1970 e 1980, receberam em bens materiais muito menos que a geração anterior e isso alterou a aproximação do materialismo, ficando mais próximos de valores familiares e círculo de amizades fortes. Disponível em: <https://dotgroup.com.br/ebook/e-book-as-geracoes-e-suas-formas-de-aprender/>. Acessado em: 01/12/02020.
} 
educador é saber trabalhar as motivações intrínsecas e mostrar ao adulto que os conhecimentos teóricos também são relevantes, tanto para as suas realizações pessoais, quanto para os anseios profissionais (BECK, 2018).

Essa fase, afirmam Fiorini, Moré e Bardagi (2017) é significativamente atravessada por questões relacionadas ao desenvolvimento da carreira e que, caso o adulto na faixa dos 20 anos não tenha realizado uma escolha profissional tende a ficar vulnerável à dúvida sobre si, à diminuição da autoestima, à ansiedade e, até mesmo, a uma possível depressão.

Por fim, de acordo com a teoria do desenvolvimento psicossocial de Erik Erikson, quando se trata do adulto jovem, uma das principais características dessa fase é o conflito pelo desenvolvimento da identidade, todavia, é possível que no decurso desse processo ocorra uma confusão de papeis que envolvem a relação com a família e com os amigos, bem como o início da relações amorosas e dúvidas sobre a identidade profissional.

A socialização adulta na fase anterior pode resultar em uma família, carreira ou amizades duradouras. Aqui, o sétimo estágio do ciclo vital de Erikson, generatividade contrapõe estagnação e diz respeito à vida adulta intermediária, a qual inicia em torno dos 40 anos e se estende, aproximadamente, até os 65 anos, por isso, é considerado o período mais longo entre os oito estágios do desenvolvimento psicossocial proposto por Erik Erikson (CARPIGIANI, 2010; PAPALIA e FELDMAN, 2013).

Essa fase do desenvolvimento humano, acrescenta Leite (2019), envolve a construção da família, a expansão e afirmação profissional que exige da pessoa produtividade, bem como, o envolvimento e cuidado com uma nova geração. De acordo com Magalhães e Gomes (2005), no modelo de estágios de vida apresentado por Erik Erikson, o compromisso com o mundo social mais amplo se dá a partir do estabelecimento de laços duradouros de intimidade, então, o sentimento de generatividade conduz o sujeito a cuidar, ensinar, liderar e promover o conforto da próxima geração.

À generatividade, enfatiza Carpigiani (2010), Erikson atribuiu o significado de criar e orientar uma nova geração. $\mathrm{O}$ adulto maduro preocupa-se com as gerações vindouras:

A evolução fez do homem um animal tanto ensinante como aprendiz, visto que dependência e maturidade são recíprocas; o homem maduro necessita ser necessitado e a maturidade é guiada pela natureza daquilo que dever ser assistido. A generatividade é, pois, de modo primordial, a preocupação em estabelecer e orientar a geração seguinte. [...] E, com efeito, pretende-se que o conceito de generatividade inclua a produtividade e a criatividade, nenhuma das quais, entretanto, pode substitui-la como designações de uma crise no desenvolvimento (ERIKSON, 1976, p. 138).

A generatividade, segundo Carvalho-Barreto (2013), transcende os limites do círculo familiar, se direciona à sociedade e as gerações futuras. Ainda, afiança o autor, é neste estágio 
que o indivíduo avalia o que realizou na vida até então e o que pretende deixar de legado à posteridade, seja na produção ou constituição de bens, ou na manutenção da humanidade pelo cuidado de outras pessoas.

O conceito de generatividade, não implica, necessariamente, em ter ou querer filhos, mas reside no desejo de contribuir para o bem-estar presente e futuro da sociedade em que se está inserido, "de criar ideias que devem se transformar em ações produtivas”, destaca Fiedler (2016, p. 84).

De acordo com Rebelo e Borges (2009), o conceito de generatividade é amplo, vai além da parentalidade ${ }^{15}$, abarca também uma preocupação extensiva à sociedade, expressa por meio de atividades de participação política e cívica, trabalho voluntário, envolvimento com instituições religiosas ou atividades espirituais, entre outras.

Ainda, Erikson (1976) considerava a generatividade um aspecto da formação da identidade, que, também, compreende todos os produtos e realizações que beneficiam o sistema social e viabilizam sua continuidade e melhoria. Assim sendo, as produções resultantes da vida profissional são fundamentais para a experiência da generatividade, o trabalho é um dos aspectos mais pertinentes da identidade individual, tanto quanto o próprio nome, o sexo e nacionalidade.

Na cultura ocidental, declaram Magalhães e Gomes (2005), o sucesso e a satisfação no trabalho reafirmam o senso de identidade e trazem reconhecimento social, por isso, a atividade profissional é percebida como a forma mais significativa de contribuição individual para a sociedade. No estabelecimento da identidade ou status social, a participação em atividades sociais não significa tanto quanto o trabalho, " as características ocupacionais normalmente se refletem em atitudes, valores e posições políticas, associadas a fatores como classe social e nível de instrução" (MAGALHÃES e GOMES, 2005, p. 72).

Nesse estágio, embora as diferenças individuais, o desenvolvimento físico apresenta uma lenta degeneração das habilidades sensoriais, da saúde, do vigor e da força física. Em termos de desenvolvimento psicossocial, a concepção de si mesmo continua a se desenvolver. O estresse pode ser ocasionado pela dupla responsabilidade pelo cuidado dos filhos e dos pais idosos. A saída dos filhos de casa deixa o ninho vazio. No que concerne ao desenvolvimento cognitivo, as capacidades mentais atingem o ápice, a especialização e as habilidades relativas à solução de problemas práticos são proeminentes. Ainda que a produção criativa decline, ela melhora em qualidade. Para algumas pessoas, o sucesso na carreira e o triunfo financeiro

\footnotetext{
${ }^{15}$ Carvalho-Barreto (2013) afirma, com base nas referências teóricas de Erik Erikson, que a parentalidade surge como uma eficaz estratégia para cuidar de alguém - um filho ou outra pessoa -, contribuindo para o futuro da sociedade. A parentalidade ultrapassa o fator biológico. O conceito de parentalidade vem sendo utilizado para descrever o conjunto de atividades desempenhadas pelos adultos que sejam responsáveis pela criança, os quais são referência da criança no seu papel de assegurar a sua sobrevivência e o seu desenvolvimento pleno.
} 
atingem o auge, para outros, poderá ocorrer o esgotamento ou a mudança de carreira (PAPALIA e FELDMAN, 2013).

No estudo realizado por Chiuzi, Peixoto e Fusari (2011), as características descritas no sétimo estágio da teoria do desenvolvimento psicossocial de Erik Erikson, são evidentes nos indivíduos da geração baby boomer ${ }^{16}$. De acordo com os autores, uma característica acentuada desta geração é a necessidade de instruir às próximas gerações, de passar adiante seus conhecimentos. No trabalho, procuram gerir pessoas por harmonia e são preocupados com o bem-estar, com a participação e a justiça para com sua equipe.

Baseando-se em Erikson (1976, p. 139), as instituições tendem a reforçar a generatividade visando a sucessão de seus trabalhadores:

Quanto às instituições que reforçam a generatividade e a salvaguardam, só podemos dizer que todas as instituições, pela sua própria natureza, codificam a ética da sucessão generativa. A generatividade é, em si mesma, uma forca propulsora na organização humana. E as fases de infância e da idade adulta são um sistema de geração e regeneração a que as instituições tais como a partilha das responsabilidades familiares e a divisão de trabalho se empenham em dar continuidade.

Enquanto a generatividade é a dimensão da personalidade que se refere ao grau de participação ativa na construção do futuro, a estagnação é o sentimento de contrapartida negativa da generatividade. À medida que o indivíduo envelhece, explica Leite (2019), o seu envolvimento com as gerações pode se perder, por não se sentirem mais necessários, são tomados por um senso de inatividade ou falta de significado para a vida.

Ao exposto, Rebelo e Borges (2009) reforçam que, o status estagnado caracteriza-se por níveis baixos de envolvimento - capacidade do sujeito de desenvolver projetos de desenvolvimento pessoal e/ou comunitário -, bem como de inclusividade, ou seja, para quem é incluído / excluído das preocupações e ações generativas.

O oitavo e último estágio do desenvolvimento psicossocial descrito por Erik Erikson é o da integridade versus desespero. Tem início, aproximadamente, após os 65 anos e corresponde à vida adulta tardia (LEITE, 2019; SEIDL-DE-MOURA et al., 2017). Segundo Papalia e Feldman (2013), o senso de integridade é baseado na reflexão, por parte dos adultos mais velhos, das conquistas e situações diversas vivenciadas ao longo da vida, eles têm de avaliar e aceitar suas vidas para poderem aceitar a morte. Ainda, sublinham as autoras,

\footnotetext{
${ }^{16}$ É a geração do pós-guerra, dos nascidos entre os anos de 1945 e 1964 . O termo baby boomer é uma referência à onomatopeia utilizada para descrever os nascidos pós Segunda Guerra Mundial, período em que houve um boom de nascimentos em função da situação socioeconômica norte-americana. Têm perfil workaholic na relação com o seu trabalho, na qual visam o retorno financeiro como principal finalidade do trabalho como estilo de vida. Valorizam a ascensão profissional, mas passaram toda ou quase toda a carreira em um único emprego. Preferem ler e seguir programas de ensino tradicionais (CHIUZI, PEIXOTO e FUSARI, 2011; PAPALIA e FELDMAN, 2013).
} 
Erikson declara que, os resultados obtidos nos sete estágios anteriores norteiam o indivíduo na luta para conquistar um senso de coerência e totalidade, ao invés de se entregar ao desespero por sua incapacidade de reviver a vida.

Haverá integridade e ganhos, se o envelhecimento ocorre com sentimento de produtividade e valorização do que foi vivido, sem arrependimentos e lamentações sobre oportunidades perdidas. Do contrário, um sentimento de tempo perdido e a impossibilidade de começar de novo trará tristeza e desesperança (CARPIGIANI, 2010; ERIKSON, 1976).

Nesse estágio, Erikson fala muito em ensinar o indivíduo a enfrentar o fechamento do seu ciclo vital, buscando a integridade e dando valor às experiências adquiridas durante os estágios anteriores:

$\mathrm{Na}$ pessoa em progressivo amadurecimento com a idade, que zelou pelas coisas e pessoas e se adaptou aos triunfos e desapontamentos de ser, necessariamente, a originadora de outras e a geradora de coisas e ideias - só nela o fruto das sete fases gradualmente amadurece. Não conheço melhor palavra para isso do que integridade (ERIKSON, 1976, p. 139).

Carpigiani (2010) reforça que esses sentimentos podem ser maximizados ou minimizados pela cultura, dependendo do papel que o velho ocupa em cada sociedade e sua importância: por um lado, o velho como um fraco, doente, sem capacidade de produzir e, por outro lado, o velho como aquele que detém a sabedoria e a ética de sua sociedade e garantem a ele um espaço de dignidade e importância.

As influências que o indivíduo exerceu nas instituições não são rejeitadas por Erikson (1976, p.141), todavia, elas serão passadas às gerações futuras não diretamente por eles, mas sim pela forma como esses valores se instauraram nas mesmas:

\begin{abstract}
Seja qual for o abismo a que as preocupações fundamentais possam conduzir os homens, individualmente considerados, o homem, como criatura psicossocial, defrontar-se-á, no final de sua vida, com uma nova edição da crise de identidade que poderíamos formular nas seguintes palavras: "Eu sou o que sobrevive de mim". Das fases da vida, portanto, disposições tais como fé, força de vontade, determinação, competência, fidelidade, amor, desvelo, sabedoria - tudo critérios de força vital individual - também fluem para a vida das instituições. Sem elas, as instituições definham; mas sem que o espírito das instituições impregne os padrões de desvelo e amor, instrução e treino, nenhuma força poderia emergir da sequência de gerações.
\end{abstract}

Segundo Papalia e Feldman (2013), ainda que a integridade deva superar o desespero para que esse estágio seja concluído com êxito, Erikson afirmava que algum desespero é inevitável. A necessidade de se lamentar é intrínseca ao ser humano, não apenas pelas próprias desventuras e oportunidades perdidas, mas pela vulnerabilidade de transitoriedade da condição humana.

Por fim, o termo integridade sugere um fim de ciclo, já que etimologicamente 
significa qualidade do que é íntegro, inteiro, completo, como se aí ficasse limitado, o que, mais uma vez, demonstra a pura enumeração de tributos, "é a aceitação pela pessoa de seu único ciclo vital e daqueles que se tornaram significantes para ela como algo que tinha de ser e que, necessariamente não permite substituição" (ERIKSON, 1976, p. 140).

O estudo de Erik Erikson contribui na compreensão do desenvolvimento do ser humano em todos os ciclos de vida. Pode-se perceber que, em cada um dos estágios aprendemos de formas diferentes. Portanto, a educação não pode ser igual para todos.

\section{AS FASES EXISTENCIAIS NA VIDA ADULTA: A TEORIA SOBRE O DESENVOLVIMENTO HUMANO DE JUAN MOSQUERA E CLAUS STOBÄUS}

Outros autores que se dedicam ao estudo das fases da vida adulta são Juan Mouriño Mosquera e Claus Dieter Stobäus. Durante a década de 1970, esses autores propuseram a divisão da vida adulta em três fases existenciais: adultez jovem, adultez média e adultez velha, conforme apresentado na Figura 9. Ainda, dentro dessas três divisões e concepções de vida adulta, cronologicamente, outras subcategorias se apresentam.

Figura 9 - Fases existenciais da vida adulta

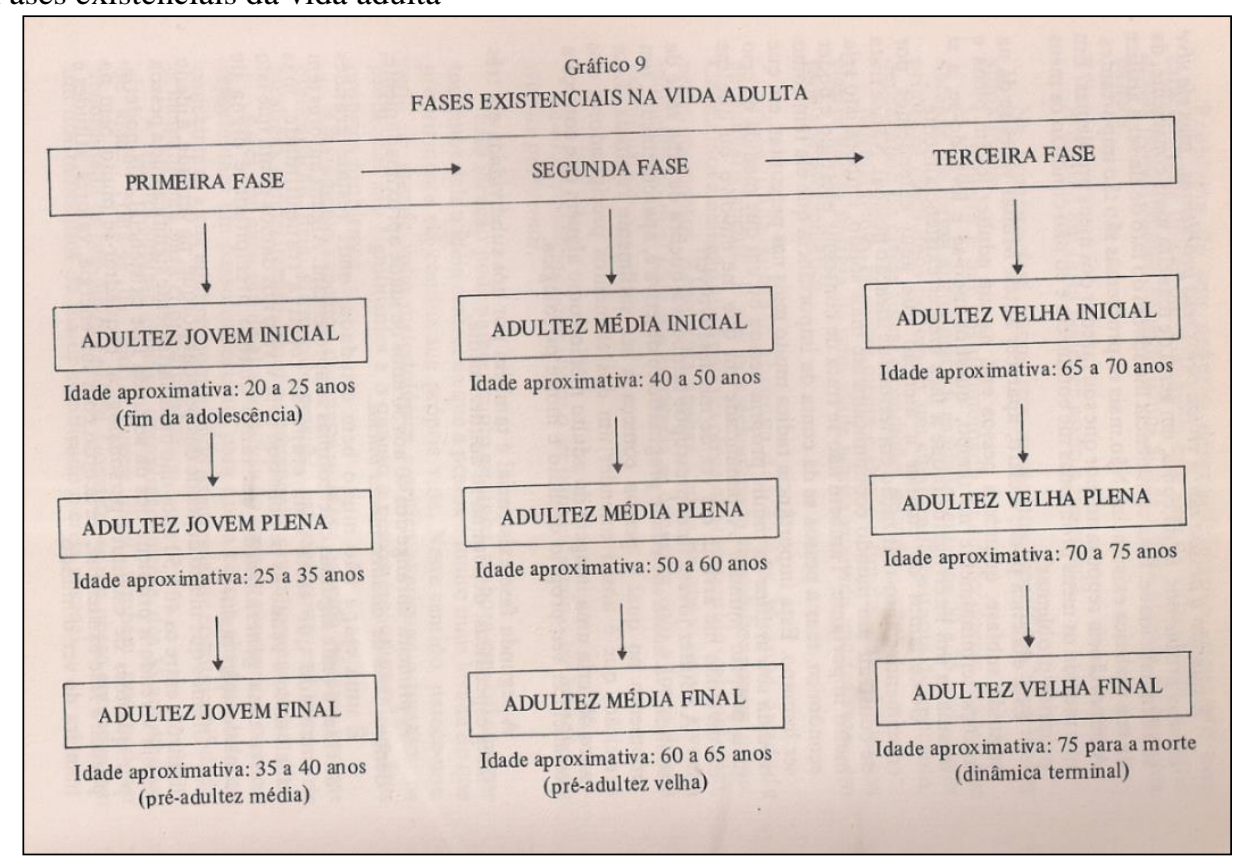

Fonte: Mosquera e Stobäus (1983, p. 86).

A partir da figura é possível identificar que os autores estabelecem faixas etárias aproximadas para cada uma das fases da vida adulta, a saber: a primeira fase - a adultez jovem, começa aproximadamente aos 20 anos e encerra aos 40 anos, idade em que se inicia a adultez média, que dura em torno de 25 anos e terminando por volta dos 65 anos. A partir dos 65 anos entramos na adultez velha, a qual se extingue com a morte.

Assim como na teoria do desenvolvimento psicossocial de Erik Erikson, Mosquera e 
Stobäus (1983, p. 84) também consideram que, bem como nas outras fases da vida, a vida adulta também tem problemas típicos para serem resolvidos "são os problemas que vivem o ser humano e não o ser humano que vive os problemas".

Santos e Antunes (2007) enfatizam que, a divisão cronológica de cada fase na vida adulta está conectada ao período em que a sociedade vivencia historicamente até a contemporaneidade, isso quer dizer que, o contexto social, cultural e até mesmo econômico em que a pessoa está inserida influencia na divisão em faixas etárias. Ainda, reforçam as autoras, as novas pesquisas socioculturais indicam um prolongamento das idades limítrofes em cada fase, resultantes dos novos entendimentos e concepções de amadurecimento e distanciamento do seio familiar.

Diante disso, no que diz respeito ao estudo de Mosquera e Stobäus (1983), a proposição desta pesquisa tem disposição dirigida à compreensão das características que permeiam as fases existenciais da vida adulta dos indivíduos a partir da metade da segunda subcategoria da primeira fase, ou seja, especificamente à adultez jovem plena e a terceira subfase - adultez jovem final, e às duas primeiras subcategorias da segunda fase, adultez média inicial e adultez média plena.

No entanto, do mesmo modo que foi tratada a teoria do desenvolvimento psicossocial de Erik Erikson, torna-se oportuna apresentar de forma sinóptica a teorização da vida adulta e suas fases, proposta por Mosquera e Stobäus.

Então, de acordo Mosquera e Stobäus (1983), a adultez jovem se subdivide em três momentos específicos e com idades aproximadas: a fase inicial, denominada adultez jovem inicial, com idade aproximada entre os 20 e 25 anos. Posteriormente, a segunda subfase é a adultez jovem plena, que compreende dos 25 aos 35 anos de idade e, por fim, a terceira subfase, a adultez jovem final, que abrange, aproximadamente, dos 35 aos 40 anos de idade.

Os autores destacam que, dependendo da classe social e condições de vida, a adultez jovem inicial pode ter significado bastante diferenciado: via de regra, é o fim da adolescência para a classes média e alta; para as classes mais baixas, se trata de uma idade adulta já vivida, muitas vezes, em toda sua problemática.

Não é à toa que Erikson introduziu o conceito de crise de identidade, para descrever o período que, repetidas vezes, transcorre na adolescência, na qual a pessoa em desenvolvimento deve construir novas habilidades, sentimentos, papeis e, inclusive, uma nova aparência física.

Ainda, eles chamam a atenção à adultez jovem plena, não pelo significado de plenitude, de terminal que a palavra significa, mas pelo fato do jovem estar, neste momento, a "todo vapor" com sua problemática. 
Nessa subfase, o adulto toma consciência da chegada em sua existencialidade adulta $\mathrm{e}$ procura pela significância e afirmação pessoal, "estes dez anos são de alta significação para se construir e, cremos, representam um passo importante para que a pessoa chegue a admitir com clareza a sua adultez, com sentido existencial de comunicabilidade, principalmente para consigo mesmo" (MOSQUERA e STOBÄUS, 1983, p. 84).

Para Mosquera e Stobäus (1983), a adultez jovem final, também denominada préadultez média é a terceira e última subfase da adultez jovem e, constitui para os autores, um momento de maior significado e crise pessoal:

É quando a pessoa não é vivida pelos seus problemas, mas ela vive os seus problemas, se dá conta, em geral de maneira mais consciente, da sua dramaticidade. Esta consciência lhe advém do fato de ela ser a artífice da sua dialética existencial. Não mais os problemas são tão importantes. A importância repousa no: por que sou o fazedor dos meus problemas? Em que medida os meus problemas me conduzem e eu não conduzo os meus próprios problemas? (MOSQUERA e STOBÄUS, 1983, p.85).

Ao final da idade adulta jovem, corroboram Santos e Antunes (2007), o indivíduo compreende, ou no mínimo imagina, o que constituirá sua realização e, as situações vivenciadas the atribuem o genuíno valor de sua existência: "não se trata de construir um mundo economicamente mais sólido, embora isto seja muito importante. Também, não se trata de conseguir prestígio e poder econômico, mas a pessoa se dá conta da importância que ela tem como ser humano" (MOSQUERA e STOBÄUS, 1983, p.85).

Ainda, sublinham Mosquera e Stobäus (1983, p. 85), na subfase adultez jovem final se pressupõe a interrupção dos sonhos:

Na nossa sociedade pragmática e objetiva é, aparentemente, um momento no qual a pessoa começa a ser sutilmente rejeitada. Esta rejeição, que é nosso entender um dos elementos precipitadores dos anos 40, cria uma imagem do adulto médio como alguém que começa a estabelecer seu próprio declínio e morte psicológica.

Acompanhando o pensamento de Erikson, Mosquera (1987) enfatiza que, na adultez jovem, emerge o estado de intimidade versus isolamento, o qual assinala a passagem para a idade adulta, cuja obrigação está em estabelecer relações íntimas, sem perder a identidade e a independência, onde o isolamento ocorre quando as defesas de uma pessoa são bastante rígidas para permitir-lhe a união com o outro e que, a intimidade "sempre requer uma disposição do adulto jovem a entregar parte dessa sua identidade tão duramente conquistada" (MOSQUERA, 1987, p. 81).

A fase adulta jovem é marcada como uma etapa de muita força e vitalidade do ser humano, onde o indivíduo adulto jovem, frente aos desafios sociais e pessoais, se encontra em 
uma série de afirmação pessoal. Diante disso, em termos de características físicas e psicológicas, Mosquera (1987, p. 80) esclarece que, nessa fase da vida há:

[...] uma grande vitalidade e uma valorização da individualidade. $\mathrm{O}$ adulto jovem está dotado dos mais fortes impulsos, os quais se manifestam, tanto pela impulsividade como pelo emprego vivo de suas forças. Seu estado de espírito frente à vida alcançou, por regra geral, um elevado nível. A alegria de viver e o prazer da existência lhe fornecem perspectivas.

A adultez jovem, segundo Santos e Antunes (2007), é caracterizada pela busca e consolidação das opções e valores pessoais, agora, integrados em um projeto de vida pessoal e profissional aperfeiçoado e realista do que aquele delineado na adolescência. Além disso, o adulto jovem cobiça a avaliação positiva de sua pessoa pelos conhecimentos até então adquiridos e construídos, bem como, espera recompensas rápidas e externas de suas motivações e busca experimentar e demonstrar muita competência, entre produções próprias de suas investidas socioeconômicas e desejos intrínsecos.

A segunda fase existencial, denominada adultez média, também é subdivida em três subcategorias específicas: adultez média inicial, adultez média plena e adultez média final.

Santos e Antunes (2007) afirmam que, na adultez média, é provável que o indivíduo já tenha atingido além dos seus objetivos desejados e sonhados na adolescência, já tenha passado por um processo de empregabilidade, já tenha constituído uma família e percebeu que necessita de novos objetivos, diferentes dos esboçados na juventude.

Comparando as mudanças e diferenças entre o adulto jovem e o adulto médio, a adultez média, entre outras percepções a respeito da vida, revela a temporalidade humana, fazendo-se consciente a imortalidade, ou seja, enquanto o adulto jovem tem a percepção de possuir o tempo ilimitado, desperdiçando desta temporalidade, o adulto maduro tem consciência da limitação temporal na realização de seus planos e procura estabelecer linhas de atuação que garantam atingir seus objetivos dentro de prazos (MOSQUERA, 1987).

Essa temporalidade faz com que os adultos maduros percebam a necessidade de se buscar habilidades e potencialidades que lhe possam ser necessárias neste processo de explorar e projetar o futuro:

Parece existir, predominantemente, uma tendência à extroversão, isto é, uma visualização para o mundo exterior. $O$ adulto médio se sente possuído pelo afã de produção e por interesses objetivos, deseja ser eficaz e ter êxito. Provavelmente para dar mais firmeza e conteúdo à segurança da sua própria pessoa (MOSQUERA, 1987, p. 96).

O que motiva o adulto, nesta fase, possivelmente, é a própria disponibilidade. O indivíduo percebe a utilidade de suas construções pessoais frente ao social, num impulso de ser útil e aprender o que é ser útil. Diante disso, espera-se na adultez média inicial, 
porventura, que se revele um adulto mais preocupado com os indivíduos que o rodeia do que propriamente com seus desejos e perspectivas, que resultem em consequências positivas ou negativas em suas subjetividades (SANTOS e ANTUNES, 2007).

Embora, nessa subfase, Mosquera e Stobäus (1983, p. 87) salientam que "muitos dramas se escondem entre os 40 e 50 anos de idade: fracassos afetivos, sexuais, medos, ansiedade e angústias", também é considerada a etapa do desempenho, da eficácia, eficiência e ideação pessoal:

Na década dos quarenta até os 55 anos de idade existe a tendência de examinar, cuidadosamente, princípios e ideais pessoais, assim como considerar fundamentalmente o desempenho coerente e autenticidade que é necessária a todo indivíduo que deseja visualizar-se como algo inteiro e não fragmentado (MOSQUERA, 1987, p. 98).

Então, diante do que já foi exposto, é possível se cogitar a possibilidade de reserva financeira e, quem sabe um processo de evolução profissional. Mosquera (1987) colabora com o exposto ao afirmar que, o fato de se ter uma maior valorização da pessoa, como indivíduo dentro da sociedade, é o que dá sentido de ir em busca de algo novo e esse ímpeto está presente em cada pessoa que se permite à chance de investir no próprio desenvolvimento e aprendizado.

Mosquera e Stobäus (2006) afirmam que, o período da vida adulta média é propício para estimular o desenvolvimento do poder criativo e a capacidade de desenvolver ideias engenhosas e produtivas. Neste cenário, uma das possibilidades de esforço para se desenvolver é voltando para a escola, a fim de ampliar o nível de formação e se manter atualizado diante das transformações da sociedade. Observando a influência da idade no retorno à escola, o relatório Educação e Deslocamento, do Censo Demográfico 2010 do IBGE, aponta que 30,1\% dos brasileiros com curso superior volta à universidade depois dos 40 anos. E, esse tipo de comportamento tende a crescer ainda mais, com o aumento da expectativa de vida da população.

A adultez média plena é a segunda subcategoria da segunda fase existencial. De acordo com Mosquera e Stobäus (1983), os mesmos sentimentos pessoais apresentados na subfase anterior, ficam evidenciados pelas percepções claras das ações sociais. As características próprias dos 50 aos 60 anos enfraquecem essas atitudes, pois as condições físicas não acompanham mais os desejos intrínsecos de cada ser humano:

De fato, o fenômeno da rejeição, já antes apontado, se faz mais nítido, especialmente após os 55 anos de idade, quando a pessoa já nota de maneira acirrada o quanto ela se torna um empecilho ante pessoas mais jovens, mais fortes e mais audaciosas (MOSQUERA e STOBÄUS, 1983, p. 87).

Na subfase posterior, adultez média final ou pré-adultez velha, a preocupação com a 
aposentadoria é exacerbada, assim como a terminalidade das atividades trabalhistas e a inoperância no desenvolvimento de uma vida de lazer (MOSQUERA e STOBÄUS, 1983; SANTOS e ANTUNES, 2007).

Neste momento da vida, Santos e Antunes (2007) reforçam que, a necessidade de ressignificar todas as condutas sociais e buscar modos significativos de viver pessoalmente, é evidenciado. Acredita-se que, a disponibilidade de tempo ou as motivações externas de sentirse bem, fomentam o desejo interno de tornar-se útil aos demais assim como a busca por uma qualidade de vida não descoberta. Estes, podem ser alguns dos aspectos que possibilitem novas vivências. "É nestes momentos que poderíamos realmente questionar, de maneira muito profunda, porque só sabemos fazer as obrigações domésticas ou profissionais, porque não aprendemos a culturar os nossos hobbies, ambições e sonhos" (MOSQUERA e STOBÄUS, 1983, p. 87).

No que diz respeito à vida adulta média como um todo, o adulto também se defronta, em vários momentos, com a tarefa de cuidar dos seus filhos adolescentes e jovens e, consequentemente, dos seus pais que envelheceram (MOSQUERA e STOBÄUS, 2006). Ainda, segundo os autores, em nossa sociedade, essas três gerações, geralmente, estão em contato direto, por isso, o cuidado com os pais idosos se converteu em um componente normativo da adultez média.

Também, é um período marcado oportunidades de crescimento e auto atualização e, ao mesmo tempo, um momento marcado por depressões orgânicas e psicológicas advindas da menopausa e da andropausa, que as pessoas experimentam ao lado de determinados conflitos, os quais, intimamente ligados às insatisfações e crises enfrentadas nesta fase.

O terceiro momento da vida adulta, denominado por Mosquera e Stobäus (1983) de adultez velha, é demarcado pelo sentido de terminalidade. Assim como as fases anteriores, também é subdividida em três momentos, os quais são a adultez velha jovem, adultez velha plena e adultez velha final.

Na primeira subfase, adultez velha inicial, a pessoa permanece ativa e são encontrados em seu comportamento, vestígios da idade adulta média. Infelizmente, neste momento, devido à nossa sociedade pragmática, os anseios e expectativas são arruinados devido ao preconceito e intolerância que se tem sobre as pessoas idosas (MOSQUERA e STOBÄUS, 1983; 2006).

A adultez velha plena, repetindo aqui que a plenitude não tem sentido de totalidade, mas de estar no auge da idade e das problemáticas, é a etapa da vida em que o indivíduo precisa provar sua capacidade de independência para a realização de algumas atividades, na busca de autonomia e reconhecimento do que ainda é capaz de fazer. A partir de então, surge sua necessidade de ser aceito como ele é, sem se sentir rejeitado pela sociedade 
(MOSQUERA e STOBÄUS, 1983; SANTOS e ANTUNES, 2007).

Por fim, no período existencial da adultez velha final, o sentimento de abandono é rodeado pela enfermidade e pela própria morte. Para Mosquera e Stobäus (1983, p. 87) “é onde o abandono, doenças e terminalidade constituem os problemas mais significativos da personalidade, que se encerra em um mundo que foi o teatro do seu desempenho e seu significado".

Como conclusão acerca das fases existenciais da vida adulta, proposta por Mosquera e Stobäus, Santos e Antunes (2007) chamam a atenção ao desenvolvimento e amadurecimento pessoal, em busca da autorrealização, ao afirmarem que, em cada etapa da vida adulta ou em suas subcategorias, sinalizam-se características de crescimento, que envolvem momentos de transições, de crises, de passagens de um estado emocional psicológico para um outro.

\section{A PERSONALIDADE DO ADULTO MADURO POR HELENA BALBINOTTI}

O tema sobre vida adulta também é objeto de estudo da psicóloga, psicanalista e psicogerontóloga Helena Beatriz Finimundi Balbinotti. Ela refere-se às pessoas a partir dos 35 anos como "maduros", indicando que a juventude começa a declinar a partir dessa idade, "o termo adulto maduro surge de um novo pensar, que procura abranger todas as pessoas a partir dos 35 - 40 anos, idade em que começam a aparecer alterações no corpo e na vida em geral, com repercussões psicológicas importantes" (BALBINOTTI, 2003, p. 25). Ainda, destaca que, embora esse momento da vida tenha idade para iniciar, pode estender-se até à morte, visto não ter idade para encerrar.

É relevante explicar que, as reflexões do estudo de Balbinotti estão contextualizadas em questões psicológicas, relacionadas às perdas decorrentes da idade. Segundo a autora, é a fase caracterizada pelo alcance de maior maturidade nos envolvimentos pessoais, sociais e profissionais:

\footnotetext{
O que define psicologicamente uma pessoa como adulto maduro é seu estado de saúde física, psíquica e intelectual. É um sujeito que sofreu uma série de vivências e transformações tanto físicas quanto psicológicas e afetivas ao longo do tempo vivido e que cumpriu algumas das principais exigências pessoais na fase adulto jovem, como: ter mantido relações com um parceiro, optado ou não pela procriação, ter exercido - ou exercer - uma atividade profissional, estabelecer relações de amizade, enfim, ter atendido socialmente às demandas necessárias (BALBINOTTI, 2003, p. 25).
}

Ainda, para Balbinotti (2003; 2017), outra característica que define o adulto maduro é que, ao ingressar nesse segundo momento da vida adulta, a pessoa se mantenha em evolução. Esse processo evolutivo é o que representa a maturidade, ele é resultado do constante exercício de reflexão e abstração, os quais, por sua vez, auxiliam na preservação da autonomia e a busca de novos sentidos existenciais. 
A autora destaca que, evolutivo é sempre o que está relacionado à capacidade de aprendizagem. $\mathrm{O}$ isolamento e a solidão estão associados à interrupção desse processo evolutivo, que se dá quando ocorre o desinteresse do adulto maduro pelas situações que o envolvem e quando ele inibe sua participação com aqueles que o rodeiam.

O envelhecimento é um processo dinâmico, natural e inevitável, uma realidade presente no ciclo humano que impõe limitações físicas, psicológicas, ambientais e sociais, as quais exigem consideração e disposição para as transformações emocionais e afetivas, possibilitando assim, a continuidade de experiências e gratificações, uma vez que, esse período é o maior do ciclo existencial (BALBINOTTI, 2012; 2017).

Diante deste cenário de vivenciar o aprender como processo contínuo, Balbinotti (2003) reforça que essa é a oportunidade de novas escolhas, de novas possibilidades, do aprimoramento das habilidades deixadas, muitas vezes, adormecidas:

[...] ao assumir uma segunda carreira profissional a ser seguida, ou por um segundo projeto, muitas vezes, necessita de apoio e auxílio para o recomeço. Ao contrário do jovem, o adulto maduro geralmente se depara com dificuldades de recomeçar em novas atividades e carece de maiores informações sobre as oportunidades disponíveis (p. 99).

Embora vivemos em um mundo globalizado e, aparentemente, sem fronteiras, temos consciência de que as fronteiras existem em diversas instâncias de nossa sociedade, como por exemplo, no acesso e permanência do adulto maduro na escola e no mundo do trabalho. $\mathrm{O}$ envelhecimento ainda é visto como um problema social e não como um processo da condição humana.

Nesse sentido, Balbinotti (2003) reflete que, em relação às novas exigências do mercado e avanços tecnológicos, os adultos maduros são tomados por sentimentos de desvalorização e desqualificação. E, aqueles que desejam prosseguir em seu processo evolutivo têm consciência da necessidade de renovarem seu autoconhecimento, bem como, aprimorarem habilidades e aptidões.

Envelhecimento e educação são processos vitais e que se relacionam ao longo de toda a vida e, devido à rapidez das alterações na demografia, relativa à população de adultos maduros, Balbinotti (2012, p. 78) defende que o aprendizado e a produção ao longo de toda a vida são do interesse da sociedade: "as pessoas precisarão de oportunidades, e a sociedade vai precisar se preparar para continuar a oferecer aos cidadãos de todas as idades condições para que não parem de se reciclar, estudar e se reavaliar".

Em todas as fases da vida, sentimentos e conquistas são fundamentais, inclusive na fase madura, "os Adultos Maduros de hoje [...] estão provando que é possível dialogar com a passagem do tempo harmoniosamente e que o sucesso não tem idade definida para ser 
alcançado" (BALBINOTTI, 2012, p. 147), demonstrando o quanto a maturidade está relacionada as novas possibilidades de escolhas.

\section{CONSIDERAÇÕES FINAIS}

A lógica da educação de adultos se baseia na afirmação que o ser humano continua aprendendo. Tanto o indivíduo quanto a sociedade, sejam quais forem as condições que se encontram, podem evoluir. Independentemente da idade e as condições de vida, o indivíduo pode aperfeiçoar-se e, a sociedade pode transformar-se, pode evoluir, seja qual for o estágio cultural e/ou educacional em que se encontre.

É fato: o aumento da expectativa de vida do ser humano traz a necessidade de reflexão sobre o tempo e o seu uso e seus significados. Se, a produção e o trabalho serão uma realidade cada vez mais presente no ritmo que está caminhando o envelhecimento populacional, a aquisição de conhecimento não poderá mais ficar restrita às primeiras décadas de vida.

Pensar em educação na vida adulta madura pressupõe que o desenvolvimento humano continue a se estabelecer em qualquer etapa da vida. A educação, enquanto um processo no desenvolvimento humano ao longo de toda a vida, deve respeitar as características de cada pessoa em seu processo de aprendizagem e de ensino, como também, atender as necessidades individuais.

Acredita-se que o grande ideal da educação deverá estar alicerçado em práticas pedagógicas coerentes com a realidade de cada aluno. Considerando que uma pessoa na fase adulta vivenciou diversas experiências, tanto na vida pessoal quanto na profissional, espera-se que ela apresente facilidades para fazer associações para determinados assuntos, dificuldades de compreensão em outros e interesse despertado em algo que está relacionado ao seu dia a dia, ao seu ambiente de convívio ou em algum ponto que tenha lhe despertado curiosidade.

\section{REFERÊNCIAS}

ALMEIDA, A. C; SUHR, I. R. F. Educação profissional no Brasil: a construção de uma proposta educativa dual. Revista Intersaberes, Curitiba, v. 7, n. 13, p. 81-110, jan./jun., 2012.

ALVES, J. E. D. O envelhecimento brasileiro até 2085 na projeção média de fecundidade. EcoDebate, Mangaratiba, dez. 2015. Disponível em: <https://www.ecodebate.com.br/2015/12/16/o-envelhecimento-brasileiro-ate-2085naprojecao-media-de-fecundidade-artigo-de-jose-eustaquio-diniz-alves/>. Acesso em: 09 ago. 2020.

ÁVILA, R. I.; MACHADO, A. M. Transição demográfica brasileira: desafios e oportunidades na educação, no mercado de trabalho e na produtividade. Indicadores Econômicos FEE. Porto Alegre, v. 43, n. 3, p. 111-124, 2016. 
BALBINOTI, H. B. F. Adulto maduro: o pulsar da vida. Porto Alegre: WS Editor, 2003.

Adulto maduro: a vida a partir dos 40 anos: conflitos, desafios e reconstruções. São Borja: Conceito, 2007.

H. B. F. A personalidade do adulto maduro: reflexões da clínica psicológica. São Borja: Conceito, 2012.

BECK, C. As 8 idades do homem: os estágios do desenvolvimento psicossocial de Erik Erikson. 2018. Disponível em: <https://andragogiabrasil.com.br/as-8-idades-do-homem/>. Acesso em: 03 out. 2020.

BERQUÓ, E. Algumas Considerações Demográficas sobre Envelhecimento da População no Brasil. In: SEMINÁRIO INTERNACIONAL "ENVELHECIMENTO POPULACIONAL:

UMA AGENDA PARA O FINAL DO SÉCULO”, I, 1996, Brasília, Anais...Brasília: Ministério da Previdência e Assistência Social, Secretaria de Assistência Social, 1996. Disponível

em: <https://biblioteca.ibge.gov.br/bibliotecacatalogo.html?id=226230\&view=detalhes $>$. Acesso em: 14 set. 2020.

BORDIGNON, N. A. El desarollo psicossocial de Eric Erikson. El diagrama epigenético del adulto, Revista Lasallista de Investigación, Antioquia, v. 2, n.2, p. 50-63, jul./dez. 2005. Disponível em: <https://www.redalyc.org/pdf/695/69520210.pdf〉. Acesso em: 03 out. 2020.

BORGES, G. M.; CAMPOS, M. B. de; SILVA, L. G. C. e. Transição da estrutura etária no Brasil: oportunidades e desafios para a sociedade nas próximas décadas. In: ERVATTI, L. R.; BORGES, G. M.; JARDIM, A. P. Mudança Demográfica no Brasil no Início do Século XXI: Subsídios para as projeções da população. Rio de Janeiro: IBGE, 2015. n. 3. p. 138-51.

BUAES, C. S. Envelhecimento e educação: em foco a aprendizagem de trabalhadores mais velhos. Revista Estudos Interdisciplinares sobre Envelhecimento. Porto Alegre, v. 6. p. 720. 2004. Disponível em: <https://seer.ufrgs.br/RevEnvelhecer/issue/view/349>. Acesso em: 07 set. 2020.

CARPIGIANI, B. Erik H. Erikson - Teoria do desenvolvimento psicossocial. Carpsi Serviços em Psicologia, Saúde e Gestão [Newsletter], ago. 2010. Disponível em: <http://www.carpsi.com.br/Newsletter_7_ago-10.pdf>. Acesso em: 03 out. 2020.

CARVAlHO-BARreto, A. de. A parentalidade no ciclo de vida. Psicologia em Estudo, Maringá, v. 18, n. 1, p. 147-156, jan./mar. 2013. Disponível em: <https://www.scielo.br/pdf/pe/v18n1/v18n1a14.pdf>. Acesso em: 13 out. 2020.

CHIUZI, R. M.; PEIXOTO, B. R. G.; FUSARI, G. L. Conflito de gerações nas organizações: um fenômeno social interpretado a partir da teoria de Erik Erikson. Temas em Psicologia, Ribeirão Preto, v. 19, n. 2, p. 579-590, dez. 2011. Disponível em: <https://www.redalyc.org/pdf/5137/513751438018.pdf>. Acesso em: 03 out. 2020.

EIZIRIK, C. L.et al. Noções básicas sobre o fundamento psíquico. In: EIZIRIK, C. L.; BASSOLS, A. M. S. (Orgs.) O ciclo da vida humana: uma perspectiva psicodinâmica. 2. ed. Porto Alegre: Artmed, 2013. p. 15-30. 
ERIKSON, Erik H. Identidade: juventude e crise. 2. ed. Rio de Janeiro: Zahar, 1976.

FIEDLER, A. J. C. B. do P. O desenvolvimento psicossocial na perspectiva de Erik H. Erikson: as "oito idades do homem", Revista Educação, Guarulhos, v. 11, n. 1, 2016. Disponível em: <http://revistas.ung.br/index.php/educacao/article/view/2265/1700>. Acesso em: 03 out. 2020.

FIORINI, M. C.; MORÉ, C. L. O. O.; BARDAGI, M. P. Família e desenvolvimento de carreira

de jovens adultos no contexto brasileiro: revisão integrativa. Revista Brasileira de Orientação

Profissional, Florianópolis, v. 18, n. 1, p. 43-55, jan./jul. 2017. Disponível em: <http://pepsic.bvsalud.org/pdf/rbop/v18n1/05.pdf>. Acesso em: 10 out. 2020.

KREUTZ, D. H.; WELTER, C. B. Professor em (re) construção: reflexões de um docente em formação pedagógica. Revista Brasileira da Educação Profissional e Tecnológica. Natal, v. 2, n. 11, p. 13-24, 2016.

LEITE, A. A. de M.; SILVA, M. L. Um estudo bibliográfico da Teoria Psicossocial de Erik Erikson: contribuições para a educação. Debates em educação, Maceió, v. 11, n. 23, jan./abril, $2019 . \quad$ Disponível em: <https://www.seer.ufal.br/index.php/debateseducacao/article/view/6332>. Acesso em: 03 out. 2020.

LEITÃO, M. História do futuro: o horizonte do Brasil do Século XXI. Rio de Janeiro: Intrínseca, 2015.

MACHADO, M. M.; RODRIGUES, M. E. C. Diversidade geracional na educação de jovens e adultos - implicações para a prática pedagógica. Revista Cadernos de Pesquisa em Educação, Vitória, ano 10, v. 19, n. 37, p. 59-78, jan./jun. 2013. Disponível em: <https://periodicos.ufes.br/educacao/article/view/7455/5235>. Acesso em: 20 maio. 2018.

MAGALHÃES, M. de O.; GOMES, W. B. Personalidades vocacionais, generatividade e carreira na vida adulta. Revista Brasileira de Orientação Profissional, São Paulo, v. 6, n. 2, p. 71-80, dez. 2005. Disponível em: 〈http://pepsic.bvsalud.org/pdf/rbop/v6n2/v6n2a07.pdf〉. Acesso em: 03 out. 2020.

MANFREDI, S. M. Educação Profissional no Brasil: Atores e cenários ao longo da história. Jundiaí: Paco Editorial, 2016.

MOSQUERA, J. J. M.; STOBÄUL, C. D. Educação para a saúde: desafio para as sociedades em mudança. Porto Alegre: Editora da Universidade, UFRGS, 1983.

MOSQUERA, J. J. M. Vida adulta: personalidade de desenvolvimento. 3. ed. Porto Alegre: Sulina, 1987.

MUSSE, I.; MACHADO, A. F. Perfil dos indivíduos que cursam a educação profissional no Brasil. Economia e Sociedade, Campinas, v. 22, n. , p. 237-262, abr. 2013. Disponível em: <http://www.scielo.br/scielo.php?script=sci_arttext\&pid=S0104-

06182013000100008\&lng=pt\&nrm=iso>. Acesso em: 13 set. 2020.

NOACK, J. Reflexões sobre o acesso empírico da teoria de identidade de Erik Erikson. 
Interação em Psicologia, Curitiba, v. 11, n. 1, p. 135-146. Jan./jun. 2007. Disponível em: <https://revistas.ufpr.br/psicologia/article/view/6543/6781>. Acesso em: 03 out. 2020.

PAPALIA, D. E.; FELDMAN, R. D. Desenvolvimento Humano, 12. ed. Porto Alegre: AMGH, 2013.

SANTOS, B. S. dos; ANTUNES, D. D. Vida adulta, processos motivacionais e diversidade. Revista Educação, Porto Alegre, v. 30, n.1, p. 149-164, jan./abr., 2007. Disponível em: $<$ https://revistaseletronicas.pucrs.br/ojs/index.php/faced/article/view/544>. Acesso em: 09 nov. 2020.

SEGNINI, L. R. P. Educação e Trabalho: uma relação tão necessária quanto insuficiente. São Paulo em Perspectiva, São Paulo, v. 14, n. 2, p. 72-81, jun. 2000. Disponível em: $<$ http://www.scielo.br/scielo.php?script=sci_arttext\&pid=S0102-

88392000000200011\&lng=pt\&nrm=iso>. Acesso em: 20 maio de 2018.

SEIDL-DE-MOURA; M; L. et al. Concepções sobre autonomia em faixas etárias diversas. Estudos de Psicologia, Campinas, v. 34, n. 2, p. 293-303, abr./jun. 2017. Disponível em: <https://www.scielo.br/pdf/estpsi/v34n2/0103-166X-estpsi-34-02-00293.pdf>. Acesso em: 26 out. 2020.

STELLA, C. O impacto do encarceramento materno no desenvolvimento psicossocial dos filhos. Educere et Educare Revista de Educação, Cascavel, v. 4, n. 8, p. 99-111, jul./dez. 2009. Disponível em: <http://erevista.unioeste.br/index.php/educereeteducare/article/view/818>. Acesso em: 10 out. 2020.

Artigo Recebido: 22 de abril de 2021.

Artigo Aceito: 14 de maio de 2021. 